\title{
Chronic Kidney Disease and Exposure to Nephrotoxic Metals
}

\author{
Sarah E. Orr and Christy C. Bridges *
}

Mercer University School of Medicine, Division of Basic Medical Sciences, 1550 College St., Macon, GA 31207, USA; sarah.elizabeth.orr@live.mercer.edu

* Correspondence: bridges_cc@mercer.edu; Tel.: +1-478-301-2086; Fax: +1-478-301-5487

Academic Editor: Alan Parrish

Received: 7 April 2017; Accepted: 5 May 2017; Published: 12 May 2017

\begin{abstract}
Chronic kidney disease (CKD) is a common progressive disease that is typically characterized by the permanent loss of functional nephrons. As injured nephrons become sclerotic and die, the remaining healthy nephrons undergo numerous structural, molecular, and functional changes in an attempt to compensate for the loss of diseased nephrons. These compensatory changes enable the kidney to maintain fluid and solute homeostasis until approximately $75 \%$ of nephrons are lost. As CKD continues to progress, glomerular filtration rate decreases, and remaining nephrons are unable to effectively eliminate metabolic wastes and environmental toxicants from the body. This inability may enhance mortality and/or morbidity of an individual. Environmental toxicants of particular concern are arsenic, cadmium, lead, and mercury. Since these metals are present throughout the environment and exposure to one or more of these metals is unavoidable, it is important that the way in which these metals are handled by target organs in normal and disease states is understood completely.
\end{abstract}

Keywords: chronic kidney disease; arsenic; cadmium; lead, mercury

\section{Introduction}

Chronic kidney disease (CKD) is becoming increasingly common worldwide. Recent estimates suggest that $8-16 \%$ of the global population is affected by some form of CKD [1]. As the prevalence of obesity, diabetes, and hypertension increases, the risk of developing CKD also increases. As CKD progresses, patients have a reduced ability to eliminate metabolic wastes, xenobiotics, and toxicants. Of particular concern is the inability of these patients to mediate the urinary excretion of prevalent environmental toxicants. Since the environment is heavily contaminated by metal toxicants such as arsenic, cadmium, lead, and mercury, human exposure to one or more of these toxicants is nearly unavoidable. Understanding the way in which these metals are handled by diseased kidneys addresses an important global health problem.

\section{Chronic Kidney Disease}

CKD is characterized by a permanent loss of nephrons and an eventual decline in glomerular filtration rate (GFR) [2]. These alterations are accompanied by structural, functional, and molecular changes in the remaining functional nephrons in an attempt to compensate for the loss of diseased nephrons. These changes include glomerular cellular and tubular hypertrophy (Figure 1), enhanced renal blood flow, and enhanced single nephron glomerular filtration rate (SNGFR) [3]. In addition, transcription and translation of RNA is enhanced which leads to increases in mRNA expression and protein levels. Together, these compensatory changes increase the delivery of solute to healthy nephrons and enhance the rate of solute uptake by tubular epithelial cells [3-6]. In general, the overall 
functional capacity of hypertrophied nephrons is enhanced as a mechanism to compensate for the loss of diseased/injured nephrons.
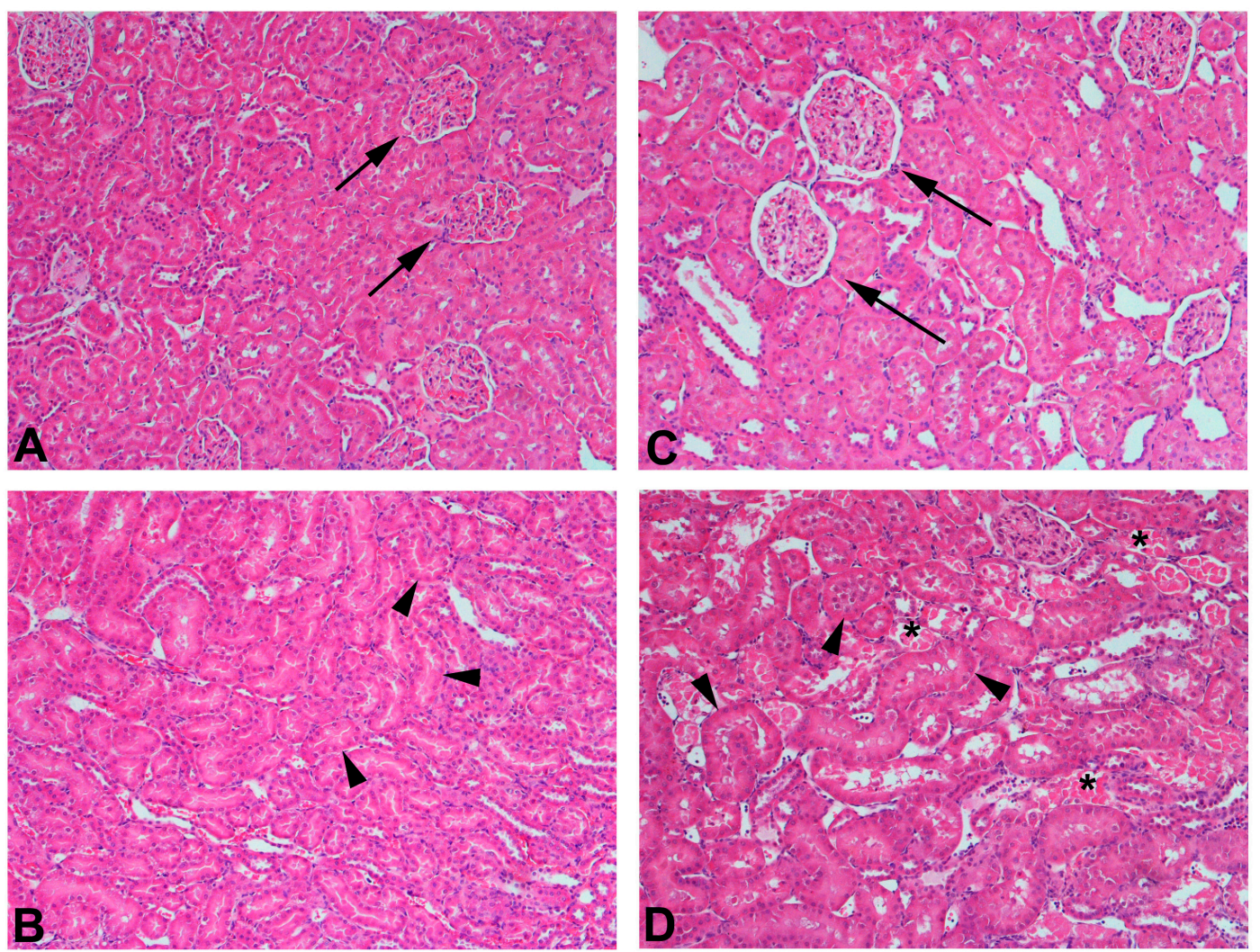

Figure 1. Histological sections of kidneys from Sham or 75\% nephrectomized Wistar rats. Normal glomeruli (arrows) and tubules from the renal cortex are shown in panel (A) while panel (B) shows normal tubules (arrowheads) from the outer stripe of the outer medulla. Sections of renal cortex (C) and outer stripe of outer medulla (D) from a 75\% nephrectomized rat are also shown. A 75\% nephrectomized rat is considered to be an appropriate model of chronic kidney disease. Glomeruli (arrows (C)) from a 75\% nephrectomized rat appear to be hypertrophied as a compensatory response to a reduction in renal mass. Similarly, the tubules in the outer stripe of the outer medulla (D) of the $75 \%$ nephrectomized rat also appear to be hypertrophied (arrowheads). In contrast, some tubules $\left(^{*}\right)$ display signs of necrosis, which is likely due to the reduced perfusion of blood to those nephrons. Magnification, $100 \times$.

Unfortunately, the compensatory changes in healthy nephrons can eventually lead to injury, sclerosis, and death of those nephrons. Once the population of functional nephrons is reduced to approximately $25 \%$ of normal, compensatory changes in nephrons are no longer sufficient to maintain fluid homeostasis, and proper renal function. When the total GFR is decreased, endogenous wastes, xenobiotics, and toxicants can accumulate in the blood and cause metabolic disturbances and/or organ intoxication [7]. The accumulation of these substances may enhance morbidity and/or mortality of patients affected by CKD.

\section{Chronic Kidney Disease and Exposure to Toxic Metals}

As described previously, CKD is associated with hyperperfusion and an increase in SNGFR $[7,8]$. Consequently, the luminal and basolateral surfaces of renal tubular epithelial cells are potentially exposed to higher levels of xenobiotics, metabolic wastes, and nephrotoxicants. In addition, these substances may be taken up more readily by hypertrophied tubular cells because of increases in the expression of certain cellular transport mechanisms [3,9]. The increased exposure to, and probable 
uptake of, available xenobiotics, metabolic wastes, and nephrotoxicants likely enhances the risk of hypertrophied tubular cells being affected adversely by these substances [10]. Indeed, it has also been suggested that exposure to heavy metals can negatively alter the function of the remaining functional nephrons [11,12]. These adverse effects could conceivably lead to additional and/or more rapid cell death and glomerulosclerosis, which would further reduce the functional renal mass of the patient. It is important to consider that as the functional renal mass of the patient is reduced, urinary excretion of xenobiotics and toxicants is also reduced, which may negatively affect the overall health of the patient. Indeed, in vivo studies show that exposure of uninephrectomized rats to nephrotoxicants results in cellular injury that is more extensive than that of normal, healthy rats exposed to the same nephrotoxicants [13].

Owing to naturally-occurring and chemically manufactured toxicants in the environment, individuals are exposed frequently over their lifetime to toxicants that have the capacity to negatively affect various organ systems. Since all relevant nephrotoxicants cannot be addressed here, we will focus on some of the most prevalent environmental metal toxicants: arsenic, cadmium, lead, and mercury.

\section{Environmentally Relevant Toxic Metals}

\subsection{Arsenic}

Arsenic (As) is a highly toxic metalloid found ubiquitously in the earth's crust. It accumulates naturally in aquifers through anthropogenic activities. In the environment, it is usually bound to oxygen, chlorine, or sulfur, and is referred to as inorganic As (iAs) [14], which is recognized by the Centers for Disease Control and Prevention as a human poison and carcinogen [14]. Humans are exposed to iAs through environmental, dietary, and occupational sources. The primary route of human exposure to iAs is via the ingestion of drinking water contaminated with iAs, as trivalent arsenite $\left(\mathrm{iAs} s^{\mathrm{III}}\right.$ ) and pentavalent arsenate $\left(\mathrm{iAs}^{\mathrm{V}}\right)[15,16]$. Furthermore, children who play often in sand may unintentionally ingest dirt contaminated with iAs. Humans may also be exposed to iAs upon ingestion of certain fish and various types of seafood, which may contain high levels of this metal. With regard to occupational sources of iAs in the United States, approximately $90 \%$ of all iAs used in industry is utilized in the pressure-treatment of wood. Workers involved in the treatment process or exposed to dust produced when the wood is cut are at higher risk for As intoxication.

Ingested iAs is readily absorbed in the intestinal tract [17] and can lead to nausea, vomiting, hyperkeratosis, anemia, diabetes, cardiovascular disease, and certain types of cancer [18-21]. Once ingested, arsenic (III) methyltransferase (AS3MT) mediates the S-adenosylmethionine (SAM)-dependent methylation of iAs to tri- and pentavalent forms of methylated arsenic [22]. AS3MT has been detected in human liver, kidney, bladder, heart, lung, testes, and adrenal gland [22,23]. In humans, the four major methylation products are methylarsenic acid $\left(\mathrm{MAs}^{\mathrm{V}}\right)$, methylarsonous acid $\left(\mathrm{MAs}^{\mathrm{III}}\right)$, dimethylarsinic acid $\left(\mathrm{DMAs}^{\mathrm{V}}\right)$, and dimethylarsinous acid (DMAs ${ }^{\mathrm{III}}$ ) $[16,24]$. It has been suggested that the trivalent forms of As, MAs ${ }^{\mathrm{III}}$ and DMAs ${ }^{\mathrm{III}}$, are more toxic than the pentavalent forms, MAs ${ }^{\mathrm{V}}$ and $\mathrm{DMAs}^{\mathrm{V}}$ [25-32].

Human exposure to methylated forms of As (MAs and DMAs) usually occurs via exposure to pesticides used for treatment of cotton crops [14]. Interestingly, ingestion of methylated forms of As appears to have fewer toxicological effects than ingestion of the same dose of iAs [14]. Exposure to high doses of Mas and DMAs are required to produce the same toxicological effects as exposure to a lower dose of iAs.

\subsubsection{Renal Handling of Arsenic}

Urinary excretion represents the major route of As elimination [33]. Since a large fraction of absorbed As is filtered at the site of the kidney, the kidney is an important site of As uptake and accumulation. Studies using yeast and Xenopus laevis oocytes suggest that the glucose transporter, GLUT1 (SLC2A1), and possibly GLUT5 (SLC2A5), may play a role in the uptake of As ${ }^{\mathrm{III}}$ and MAs ${ }^{\mathrm{III}}$ at 
the basolateral membrane of proximal tubular cells (Table 1) [34]. These carriers are localized in the basolateral membrane of proximal tubular cells $[35,36]$ and may mediate the uptake of As ${ }^{\mathrm{III}}$ and MAs ${ }^{\mathrm{III}}$ from peritubular capillaries into proximal tubular cells. Interestingly, studies in Xenopus laevis oocytes suggest that the uptake of As ${ }^{\mathrm{III}}$ may also be mediated by aquaporin 3 (AQP3) [37]. AQP3 is localized in the basolateral membrane of renal distal tubules and collecting ducts [38] and, thus, it may play a role in the basolateral uptake of As ${ }^{\mathrm{III}}$ by renal tubules. In addition, the organic anion transporting polypeptide, OATP2B1 (SLCO2B1), may be involved in basolateral uptake of some forms of As [39]. This carrier has been implicated in the proximal tubular uptake of cisplatin and since cisplatin and As are both heavy metals, it is possible that OATP2B1 may also play a role in the uptake of arsenicals [40]. However, there is no direct evidence suggesting that OATP2B1 is capable of mediating the transport of any form of As.

Table 1. Potential mechanisms involved in the renal tubular transport of arsenic.

\begin{tabular}{|c|c|c|}
\hline & Transport Mechanism & Species \\
\hline Apical uptake & $?$ & $?$ \\
\hline \multirow{4}{*}{ Basolateral uptake } & GLUT1 & $\mathrm{As}^{\mathrm{III}}$ and MAs ${ }^{\mathrm{III}}$ \\
\hline & GLUT5 & $A s^{I I I}$ and MAs ${ }^{I I I}$ \\
\hline & Aquaporin 3 & $A s^{I I I}$ \\
\hline & OATP2B1 & $?$ \\
\hline \multirow{4}{*}{ Apical export } & MRP2 & $\operatorname{As}(\mathrm{GS})_{3}, \operatorname{MAs}(\mathrm{GS})_{2}$ \\
\hline & P-glycoprotein & iAs, $\mathrm{As}(\mathrm{GS})_{3}, \mathrm{MAs}(\mathrm{GS})_{2}$ \\
\hline & MRP4 & $\mathrm{iAs}^{\mathrm{III}}, \mathrm{iAs}^{\mathrm{V}}, \mathrm{MAs}^{\mathrm{III}}, \mathrm{MAs}^{\mathrm{V}}, \mathrm{DMA}^{\mathrm{V}}$ \\
\hline & MATE & $?$ \\
\hline \multirow{3}{*}{ Basolateral export } & GLUT1 & $\mathrm{As}^{\mathrm{III}}$ and MAs ${ }^{\mathrm{III}}$ \\
\hline & GLUT5 & $A s^{I I I}$ and MAs ${ }^{I I I}$ \\
\hline & OATP2B1 & As ${ }^{\mathrm{III}}$ and MAs ${ }^{\mathrm{III}}$ \\
\hline
\end{tabular}

GLUT: glucose transporter; OATP: organic anion transporting polypeptide; MRP: multidrug resistance-associated protein; MATE: metal and toxicant extrusion protein.

The mechanisms by which iAs ${ }^{\mathrm{III}}$ and MAs ${ }^{\mathrm{III}}$ are transported out of renal tubular epithelial cells are not completely clear at present. However, it has been suggested that since GLUT1 and GLUT5 are capable of bidirectional transport, they may be able to mediate the export of $A s^{\mathrm{III}}$ and MAs ${ }^{\mathrm{III}}$ [41]. Similarly, OATP2B1 has been shown to mediate bi-directional transport of certain substrates and, thus, it may also be capable of mediating the export of $\mathrm{As}^{\mathrm{III}}$ and MAs ${ }^{\mathrm{III}}$ [41]. The ability of these carriers to mediate the efflux of any species of As has not been shown.

Alternatively, glutathione (GSH) conjugates of arsenicals may be transportable forms of As at the site of specific transport proteins in renal tubular epithelial cells. Indeed, studies using in vitro models suggest that the transport of As in certain cells is dependent upon the availability of GSH [42-44]. Like many other metals, iAs $s^{\mathrm{III}}$ and MAs ${ }^{\mathrm{III}}$ appear capable of binding to free GSH, thereby forming more transportable forms of As, (i.e., $\mathrm{As}(\mathrm{GS})_{3}$ and $\mathrm{MAs}(\mathrm{GS})_{2}$, respectively) [45]. It appears that iAs III and GSH form a complex consisting of three GSH molecules bound to one As atom (As(GS) $)_{3}$ [46,47]. Similarly, one atom of MAs may bind to two GSH molecules to form MAs(GS)2. The resulting arsenic species may be exported into the tubular lumen via apical export proteins such as the multidrug resistance-associated protein 2 (MRP2; ABCC2) and/or P-glycoprotein (MDR1; ABCB1) [48]. Interestingly, exposure of mice to inorganic species of As, enhanced the mRNA expression of MRP2 [49]. Similarly, exposure of cultured hepatocytes to sodium arsenite or sodium arsenate led to a dose- and time-dependent increase in the mRNA expression of MRP2 [49]. The As-induced increase in expression of MRP2 suggests that this carrier plays an important role in the export of As ions out of the cells for eventual excretion in the urine. Additional studies in cultured hepatocytes demonstrate that $\mathrm{As}(\mathrm{GS})_{3}$ and MAs $(\mathrm{GS})_{2}$ are exported out of hepatocytes into bile via MRP2 [50,51]. Since MRP2 is also found in the apical membrane of proximal tubular cells [52], it is possible that MRP2 and P-glycoprotein may 
also play roles in the export of arsenic species from proximal tubular cells. In vivo experiments in mice treated with MK-571, an inhibitor of MRP2, showed that inhibition of this carrier reduced the urinary excretion of As by $50 \%$ [42]. More direct studies indicate that $\mathrm{As}(\mathrm{GS})_{3}$ and $\mathrm{MAs}(\mathrm{GS})_{2}$ can be transported out of proximal tubular cells via MRP2 [37,53]. Similarly, MRP4 (ABCC4), which is also present on the apical plasma membrane of proximal tubular cells, appears to play a role in the export of iAs ${ }^{\mathrm{III}}, \mathrm{iAs}^{\mathrm{V}}, \mathrm{MAs}^{\mathrm{III}}, \mathrm{MAs}^{\mathrm{V}}$, and/or DMA ${ }^{\mathrm{V}}$ [54].

With regard to P-glycoprotein, studies using $m d r 1$ knockout mice suggest that there is an additional transporter involved in the export of As complexes out of renal tubular epithelial cells [42]. In addition, in vivo studies have shown that the expression of P-glycoprotein in the kidney is upregulated following As-induced cellular injury $[55,56]$. Studies in $m d r 1$ knockout mice indicate that the accumulation of iAs is greater in liver, kidney, and small intestine of the knockout mice compared to wild type. The knockout mice were also more susceptible to intoxication by As than wild type mice $[57,58]$. Together, these data suggest that P-glycoprotein may be involved in the export of iAs into the tubular lumen for excretion in urine.

The metal and toxicant extrusion protein (MATE; SLC47A1) may also play a role in the export of As compounds at the luminal membrane of proximal tubular cells. This carrier is localized in the apical membrane of proximal tubular cells and has been shown to mediate the export of a wide variety of xenobiotics and toxicants [59]. There are no data suggesting that it may mediate the export of As compounds, however, it has been shown to mediate the export of $\mathrm{Cd}[60]$ and, thus, we suggest that it may also play a role in the export of As.

\subsubsection{Renal Effects of Arsenic Exposure}

Acute arsenic-induced renal intoxication may lead to tubulointerstitial nephritis and acute tubular necrosis [61]. As-induced kidney injury is characterized by hypercalciuria, albuminuria, nephrocalcinosis, and necrosis of the renal papillae [14,62]. In vivo and in vitro studies suggest that transport of iAs into cells may lead to alterations in intracellular signaling processes. Exposure of mice to iAs reduced the expression of raf kinase inhibitor protein (RKIP) [63], which is involved in the regulation of multiple cell signaling cascades [64-66]. RKIP is thought to play an important role in the regulation of growth and the survival of cells, suggesting that downregulation of its expression may lead to uncontrolled growth of cells and cancer [66]. In addition, exposure to As compounds appears to lead to DNA methylation and histone acetylation, which, in turn, may cause epigenetic alterations in the expression of interleukin-8 (IL-8) in renal tubular cells [67]. These alterations have been shown to result in proneoplastic changes such as increased migration, proliferation, and cell-cycle dysregulation in renal cells [67]. These types of alterations may represent early steps in the progression of certain types of cancer.

Cellular injury and death following exposure to iAs is likely related to the As-induced generation of reactive oxygen species (ROS) [68]. Indeed, oxidative stress has been shown to be a mechanism of iAs-induced cellular intoxication [69]. Oral exposure of rats to or direct treatment of cells with sodium arsenite has been shown to increase production of ROS and reactive nitrogen species (RNS); enhance lipid peroxidation, protein carbonylation, DNA oxidation; and reduce antioxidant defenses [70-72]. Similarly, exposure of cultured renal epithelial cells (HEK-293) to iAs led to elevated ROS and enhanced the expression of heme oxygenase (HMOX1), which regulates heme oxidation and stress responses [73]. Mitochondria appear to be important targets of As-induced cellular toxicity in that they are highly sensitive to oxidative injury $[74,75]$.

Interestingly, in vivo and in vitro experiments have shown that exposure to arsenicals enhances the expression of metallothionein (MT) in a dose-dependent manner [76-78]. Computational modeling suggests that As binds to free thiols on the MT molecule $[79,80]$, which may reduce the oxidative injury induced by exposure to As [81]. Interestingly, it has been suggested that the formation of MT-As complexes does not occur following acute exposure to iAs; rather, it was postulated that these complexes are formed only in cases of chronic exposure [82]. 


\subsubsection{CKD and the Effects of Arsenic Exposure on the Kidneys}

Environmental, occupational, and dietary exposure to As appears to contribute to the incidence of renal injury and the development of renal disease. Contamination of drinking water with As has been linked to the development of hypertension and renal injury $[15,83]$. Similarly, a review of 24 case studies suggests that there is a positive association between exposure to iAs and kidney injury. Exposure to iAs was shown to cause albuminuria and proteinuria but it did not enhance other outcomes (e.g., anemia, hyperkalemia, hypocalcemia) that are associated with CKD. Therefore, the authors concluded that although exposure to iAs appears to cause renal injury, there is not a clear association between iAs exposure and the development of CKD [22]. In contrast, findings from a cross-sectional study of patients in Taiwan showed a positive correlation between urinary levels of As and the incidence of CKD. It was concluded that high levels of urinary As may increase the risk of developing CKD by four-fold [84]. The increased risk of CKD as a consequence of As exposure may be due to nephron death and compensatory changes in healthy nephrons that lead to a progressive loss of nephrons. In support of this idea, results from the National Health and Nutrition Examination Survey 2009-2012 indicate that early, acute exposure to As may lead to increased GFR [83], which suggests that as nephrons are injured, the remaining healthy nephrons compensate by increasing SNGFR and ultimately, total GFR [85]. When compensatory changes lead to injury and death of healthy nephrons, patients may develop CKD. When CKD develops, the urinary excretion of As and other toxicants has been shown to decrease, which may lead to additional toxicological effects in target cells and organs [86].

\subsection{Cadmium}

Cadmium (Cd) is a prevalent environmental pollutant and nephrotoxicant. Industrial uses of $\mathrm{Cd}$ include manufacture of batteries, pigments, coatings, and plastics [87]. Current regulations regarding $\mathrm{Cd}$ emissions and disposal have reduced occupational exposure to $\mathrm{Cd}$, yet the environment surrounding areas where $\mathrm{Cd}$ is/was used industrially remain heavily contaminated. Additionally, the use of this metal in phosphate fertilizers can leave soil and water contaminated heavily with Cd residue. Cd concentrates in soils and subsequently accumulates in plants, particularly root vegetables, grains, and tobacco [88]. Cd is also present in high concentrations in aquatic animals, such as seals and mollusks, and in crustaceans, such as oysters and crabs [88].

Diet is the primary means by which the general, non-smoking population is exposed to $\mathrm{Cd}$ [88]. In contrast, because of the high concentration of $\mathrm{Cd}$ in tobacco, individuals who smoke tobacco products are exposed regularly to this metal [88]. Indeed, most cigarettes contain approximately $1-2 \mu \mathrm{g}$ of $\mathrm{Cd}$ [89]. About $10 \%$ of the $\mathrm{Cd}$ contained in a cigarette is inhaled [90], with approximately $50 \%$ of that being absorbed in the lungs [91]. Therefore, it is estimated that individuals who smoke one pack of 20 cigarettes each day will absorb approximately 1-2 $\mu \mathrm{g}$ of $\mathrm{Cd}$ daily [92]. Cd is also present in air and drinking water in various regions of the world, although the concentration of $\mathrm{Cd}$ in air is relatively low and drinking water is normally not a major source of exposure for the general population $[88,92,93]$.

In a recent assessment by the US Centers for Disease Control and Prevention, as part of the National Health and Nutrition Examination Study (NHANES), blood and urine of over 5000 individuals was analyzed for $\mathrm{Cd}$. In individuals over the age of 20, the average blood level was $0.376 \mu \mathrm{g} / \mathrm{L}$ while the average urinary concentration of Cd was $0.232 \mu \mathrm{g} / \mathrm{L}$ [94]. Both urinary and blood levels of $\mathrm{Cd}$ have remained fairly steady over the past decade. These data suggest that individuals continue to be exposed chronically to $\mathrm{Cd}$. Thus, a thorough understanding of the effects of exposure to $\mathrm{Cd}$ on an organ system is important to overall human health.

\subsubsection{Renal Handling of Cadmium}

$\mathrm{Cd}$ appears to gain access to renal epithelial cells via several different mechanisms. Cd ions have a strong affinity for sulfur groups and, thus, they may form complexes with select sulfhydryl 
(thiol)-containing biomolecules, such as GSH, cysteine (Cys) or homocysteine (Hcy) $[95,96]$. These Cd-thiol complexes may gain access to cells at the site of membrane transporters involved normally in the transport of endogenous amino acids, oligopeptides, organic anions, or organic cations (Table 2) $[97,98]$. One such example is the uptake of $\mathrm{Cd}$ via the organic cation transporter 2 (OCT2; SLC22A2) $[99,100]$. OCT2 is localized in the basolateral membrane of proximal tubular cells and is involved in the transport of a wide variety of cationic substances $[101,102]$. The exact species of Cd taken up by OCT2 has yet to be determined.

Table 2. Potential mechanisms involved in the renal tubular transport of cadmium.

\begin{tabular}{ccc}
\hline & Transport Mechanism & Species \\
\hline \multirow{4}{*}{ Apical uptake } & Receptor-mediated endocytosis & $\mathrm{CdMT}$ \\
& DMT1 & $\mathrm{Cd}^{2+}$ \\
& ZIP8 & $\mathrm{Cd}^{2+}$ \\
ZIP14 & $\mathrm{Cd}^{2+}$ \\
\hline Basolateral uptake & OCT2 & Thiol S-conjugate of Cd \\
\hline & MATE1 & $\mathrm{Cd}^{2+}$ \\
Apical export & MATE2-K & $\mathrm{Cd}^{2+}$ \\
& MRP2 & Thiol S-conjugate of Cd \\
& P-glycoprotein & Thiol S-conjugate of Cd \\
& MRP4 & $?$ \\
\hline Basolateral export & BCRP & $?$ \\
\hline
\end{tabular}

DMT: divalent metal transporter; ZIP: ZRT/IRT-like protein; MATE: metal and toxicant extrusion protein; MRP: multidrug resistance-associated protein; BCRP: breast cancer resistance protein.

Cd may also be taken up by proximal tubules as a CdMT complex. Cd present in the liver becomes associated with MT to form CdMT [103,104], which may be released into sinusoidal blood following Cd-induced hepatocellular necrosis. CdMT is filtered freely at the glomerulus and is then thought to be taken up at the luminal plasma membrane of proximal tubular epithelial cells via receptor-mediated endocytosis [98,105-113]. This route of uptake appears to be a major route for entry of Cd at the luminal membrane of proximal tubular cells [114]. Indeed, the cells of the proximal convoluted tubule are the primary sites affected adversely by CdMT [103,107,109,115-119]. Following uptake by proximal tubular cells, CdMT is delivered to endosomes and lysosomes where $\mathrm{Cd}^{2+}$ is dissociated from MT and transported into the cytoplasm via the divalent metal transporter 1 (DMT1; SLC11A2) [106,120]. DMT1 is also localized in the luminal plasma membrane of the epithelial cells lining the ascending thick limb of the loop of Henle, the distal convoluted tubule, and the principal cells of the cortical collecting duct [121] where it may play a role in the uptake of $\mathrm{Cd}$ ions and lead to adverse effects within these cells.

Cd ions may also be taken up at the luminal membrane of proximal tubular cells via a mechanism involving ligand exchange. Under certain conditions, Cd may dissociate from MT or other ligands [122] and may be taken up subsequently by a cation transporter. Indeed, certain zinc transporters appear to be capable of utilizing $C d$ ions as substrates. In vitro studies in cultured renal epithelial cells have shown that ZIP8 (ZRT/IRT-like protein; SLC39A8) and ZIP14 (SLC39A14) are able to mediate the uptake of Cd ions [113,123-126]. Both of these carriers have been identified in the kidney [127] and appear to play important roles in the accumulation of $\mathrm{Cd}$ ions in proximal tubular cells. Interestingly, studies in HEK-293 cells have shown that a mutation (Ala391 to Thr391) in ZIP8 enhances Cd uptake into the kidney and vascular endothelial cells [128]. It is likely that $\mathrm{Cd}$ ions and $\mathrm{Cd}$-thiol complexes utilize additional mechanisms to gain access to renal epithelial cells; however, those mechanisms and processes remain unclear at present.

Recent studies using HEK-293 cells stably transfected with multidrug and toxin extrusion protein (MATE1; SLC47A1) or MATE2-K (SLC47A2) have shown that these carriers are able to mediate the 
export of $\mathrm{Cd}$ from within proximal tubular cells into the tubular lumen [60]. MATE1 and MATE2-K are localized in the luminal membrane of proximal tubular cells $[129,130]$ and appear to be involved in the urinary excretion of $\mathrm{Cd}$. Other transporters localized in the luminal membrane that may play a role in the export of $\mathrm{Cd}$ include MRP2, MRP4, breast cancer resistance protein (BCRP; ABCG2), and P-glycoprotein. Studies in cultured human intestinal cells provide indirect evidence suggesting that MRP2 and P-glycoprotein may be involved in the transport of Cd [131]. Currently, there are no data supporting a role for MPR4 or BCRP in the transport of Cd.

\subsubsection{Renal Effects of Cadmium Exposure}

Exposure to $\mathrm{Cd}$ is often assessed by measuring the concentration of $\mathrm{Cd}$ in urine and/or blood. In fact, urinary excretion of $\mathrm{Cd}$ is considered to be one of the most reliable indicators of renal and body burden of Cd. Detection of Cd in urine typically represents chronic levels of exposure $[92,132,133]$ while plasma levels of $\mathrm{Cd}$ usually represent a more recent exposure, such as one occurring within the previous month $[92,132,134]$. Cd has a long half-life within the body, partly due to its incorporation into bone [87]. Therefore, following exposure, decades may be required for complete elimination of this toxic metal [92].

Following chronic exposure to $\mathrm{Cd}$, approximately $50 \%$ of the total body stores accumulate in the kidney $[135,136]$. Thus, it is not surprising to find that this organ is one of the primary targets of Cd intoxication [137]. Renal accumulation of Cd leads to reduced GFR, polyuria, and generalized tubular dysfunction (i.e., Fanconi's syndrome) $[132,136,138]$. One of the earliest signs of renal damage is the presence of urinary biomarkers such as kidney injury molecule-1 (Kim-1), $\beta_{2}$-microglobulin, $N$-acetyl- $\beta$-D-glucosamidase (NAG), and cystatin $C[132,137]$. $\beta_{2}$-microglobulin is a low molecular weight protein that is filtered freely at the glomerulus and is absorbed normally by proximal tubules [139]. Following tubular damage, a small fraction of $\beta_{2}$-microglobulin escapes reabsorption and is excreted in urine. Alternatively, NAG is derived from mitochondria within proximal tubular epithelial cells and is released into the tubular fluid after cells are injured [140]. Kim-1, which is a transmembrane protein not normally detectable in urine, has also been shown to be a sensitive marker of renal tubular cell injury and/or death [141]. More recently, cystatin C, a cysteine protease inhibitor, has been shown to be a reliable biomarker of Cd-induced renal cell injury [137].

Recently, studies have shown that chronic exposure to even low levels of $\mathrm{Cd}$ can result in early signs of renal toxicity [138,142-146]. The earliest sign of Cd-induced renal damage is microproteinuria, which is usually characterized by the presence of $\beta_{2}$-microglobulin in urine $[88,92]$. The observed microproteinuria may be due to a Cd-induced loss of megalin and cubilin, which mediate endocytosis of proteins along the proximal tubule [147-150]. Longer exposures to Cd cause shortening and loss of proximal tubular microvilli, which, consequently, leads to significant reductions in the number of transporters [147]. A reduced ability to absorb substrates taken up normally by proximal tubular cells can lead to the presence of a Fanconi's syndrome characterized by glucosuria, aminoaciduria, hyperphosphaturia, and hypercalciuria $[88,147]$. In addition, autophagy and apoptosis are induced in intraglomerular mesangial cells [151,152], glomeruli are injured and, consequently, GFR is reduced $[88,92,153,154]$. The incidence of kidney stones also increases in individuals exposed chronically to (or to larger doses of) Cd, possibly due to the increased concentration of calcium in tubular fluid and urine [155]. Owing to the fact that the active form of vitamin D (1,25-dihydroxycholecalciferol) is formed in the kidneys, it is possible that renal injury would impede the conversion of the inactive form of this vitamin to the active form. Indeed, studies from Cd-polluted areas report an association between Cd-induced renal damage and lowered plasma levels of active vitamin D [156,157].

Exposure to $\mathrm{Cd}$ leads to increases in superoxide dismutase, catalase, glutathione peroxidase [158,159], and heme oxygenase [160]. Interestingly, a decrease in the expression of heme oxygenase leads to greater levels of $\mathrm{Cd}$-induced apoptosis. $\mathrm{Cd}$ has also been shown to reduce the expression of certain miRNAs, specifically miRNA 125-a, and 125-b. Under normal conditions, 
miRNAs 125-a and 125-b are thought to be involved in the suppression of Cd-induced apoptosis [161]. Reductions in the expression of these two miRNAs would promote apoptosis induced by $\mathrm{Cd}$ and possibly other heavy metals.

Zinc has been shown to reduce renal toxicity induced by Cd [162-164], possibly by blocking the ability of $\mathrm{Cd}$ to alter anti-oxidant enzymes. Zinc also induces the renal and hepatic expression of MT [165]. Increased expression of MT will enhance the formation of MT-Cd complexes in the liver and kidney, which will enhance retention of a non-toxic form of Cd [166,167]. Zinc has also been shown to reduce Cd-induced apoptosis in renal cells [168] and may also compete with Cd for entry into cells at the site of select transporters [169].

Interestingly, $\mathrm{Mg}$ has also been shown to reduce $\mathrm{Cd}$-induced toxicity. One possible pathway is via the stimulation of GSH synthesis, which would reduce the antioxidant effects of Cd $[170,171]$. In addition, $\mathrm{Mg}$ may compete with $\mathrm{Cd}$ at the site of transporters that mediate the uptake of $\mathrm{Cd}$, thereby reducing the uptake of $\mathrm{Cd}$ [172]. Consequently, the presence of $\mathrm{Mg}$ reduces lipid peroxidation and oxidative stress $[162,173]$. This may be because Mg serves as a cofactor for enzymes needed to reduce ROS.

\subsubsection{CKD and the Effects of Cadmium Exposure on the Kidneys}

Epidemiological studies have demonstrated a positive correlation between kidney disease and the renal accumulation of $\mathrm{Cd}$ in individuals exposed chronically to this metal $[145,174-178]$. Since a decline in the normal filtration capacity of the kidney is associated with CKD, exposure of individuals with $\mathrm{CKD}$ to $\mathrm{Cd}$ may potentiate the negative effects of disease-induced renal dysfunction. Consequently, it is reasonable to postulate that exposure of individuals with CKD to Cd may be especially detrimental to target organs. In diseased kidneys, the threshold at which nephrotoxic effects are observed may be lower than in healthy kidneys. Indeed, it has been suggested that long-term exposure to Cd exacerbates the CKD-related decline in GFR [179-182]. Moreover, exposure to Cd or other nephrotoxicants may further reduce or completely eliminate the renal functional reserve and the ability of the remaining functional renal mass to maintain normal homeostasis when challenged [12,183-185]. Indeed, Sprague-Dawley rats exposed chronically to oral $\mathrm{Cd}$ have been shown to have less renal functional reserve than unexposed rats [12]. Collectively, these studies suggest that exposure to Cd, and perhaps other nephrotoxicants, can abolish renal functional reserve, which may increase the susceptibility of these individuals to renal failure resulting from other risk factors such as hypertension and diabetes.

Analyses of data from the 1999-2006 National Health and Nutrition Examination Surveys (NHANES) found that chronic exposure to low levels of $\mathrm{Cd}$ is associated with albuminuria. It can be postulated that continued exposure to Cd will enhance the risk of developing CKD [175]. Indeed, a cross-sectional study of individuals living in areas of Sri Lanka that are heavily contaminated with heavy metals, such as $\mathrm{Cd}$, reported that exposure to $\mathrm{Cd}$ is a risk factor for the development of CKD [186]. Similarly, a cross-sectional study of individuals participating in the Korean National Health and Nutrition Examination Study (KHNANES) reported that exposure to Cd was associated with the development of CKD. This trend was particularly true in adults with hypertension and diabetes, which are considered to be major risk factors for CKD [187]. Despite multiple studies that appear to link exposure to $\mathrm{Cd}$ with the development of $\mathrm{CKD}$, a few studies suggest that there is no connection between exposure to $\mathrm{Cd}$ and CKD. The discrepancy between these groups of studies suggests that additional environmental, dietary, and/or genetic factors may play a role in the susceptibility to $\mathrm{Cd}$ and the development of CKD $[188,189]$.

Much of the data regarding the effects of Cd exposure on CKD comes from cross-sectional epidemiological studies because it is difficult to develop experimental models of chronic CKD. Alternatively, experimental reduction of renal mass via uninephrectomy creates a pathological scenario that is somewhat similar to that of CKD. In uninephrectomized animals, the remnant kidney undergoes significant compensatory changes in order to maintain normal fluid and solute homeostasis $[9,190]$. 
These changes include increased transcription and translation of numerous proteins, (including membrane transporters and metal-binding proteins (MT1 and MT2)) $[9,190,191]$. An increase in the number and/or activity of mechanisms involved in the proximal tubular uptake of $\mathrm{Cd}$ may enhance the nephropathy induced by this metal. When uninephrectomized and sham Sprague-Dawley rats were exposed to $\mathrm{Cd}$, the renal burden of $\mathrm{Cd}$ was greater in the remnant kidney of uninephrectomized rats than in the corresponding kidney of sham rats [119]. In addition, the urinary excretion of NAG and $\mathrm{Cd}$ was greater in uninephrectomized rats than in sham rats. Furthermore, when a toxic dose of $\mathrm{Cd}$ was administered to each group of rats, it was found that uninephrectomized rats were more susceptible to the toxic effects of $\mathrm{Cd}$ than corresponding sham rats [119]. Considering these data, it is logical to propose that exposure to $\mathrm{Cd}$ following a reduction in functional renal mass may lead to more severe nephropathy [119].

Diseases such as hypertension and diabetes that affect renal health are common throughout the world. Therefore, it is important to understand the relationship between $\mathrm{Cd}$ exposure and superimposed diseases. Numerous epidemiological and animal studies have provided evidence suggesting an association between exposure to $C d$ and the occurrence and severity of diabetes [188,192-194]. While diabetes alone may lead to decreased GFR, albuminuria, and morphological alterations along the nephron [195], chronic exposure to Cd may enhance the onset of these negative renal effects [192]. Indeed, studies in which normal Sprague-Dawley rats were injected intraperitoneally with Cd showed that administration of Cd induced hyperglycemia [196,197]. This hyperglycemia may be the result of increases in levels of the gluconeogenic enzymes, glucose-6-phosphatase, fructose-1,6-diphosphatase, phosphoenol pyruvate carboxykinase, and pyruvate carboxylase [197]. Exposure of rats to Cd also appears to decrease the gene expression and release of insulin [198-200]. Taken together, these studies suggest that exposure to $\mathrm{Cd}$ may increase one's susceptibility of developing diabetes. Exposure to $\mathrm{Cd}$ may also promote the development of signs and symptoms in a diabetic patient. Diabetes-induced renal pathology may be observed earlier in patients that are exposed chronically to low levels of $\mathrm{Cd}$ compared with un-exposed patients. This theory is supported by studies comparing streptozotocin-induced diabetic Wistar rats and non-diabetic Wistar rats [201]. The findings from these studies showed that urinary levels of protein, NAG, and $\gamma$-glutamyltransferase were greater in diabetic rats than in controls, suggesting that renal damage was more extensive in diabetic rats [201]. In addition, diabetic rats were found to excrete less $\mathrm{Cd}$ in urine and consequently had a greater renal burden of $\mathrm{Cd}$ than that of non-diabetic rats, suggesting a decrease in GFR [201]. In a similar study it was found that exposure of diabetic Sprague-Dawley rats to $\mathrm{Cd}$ significantly increased the urinary excretion of albumin, transferrin, and IgG [202]. In a separate study, varying concentrations of CdMT were injected into normal or obese hyperglycemic (ob/ob) mice [203]. Pathological signs of nephron damage (proteinuria and calciuria) were observed at lower concentrations of $\mathrm{Cd}$ in the ob/ob mice than in normal mice suggesting that the hyperglycemic state increases susceptibility to cadmium-induced nephropathy [203].

The results of multiple epidemiological studies correlate well with the aforementioned animal studies and provide additional support for the notion that exposure to $\mathrm{Cd}$ enhances the renal pathology associated with diabetes. In a cross-sectional study carried out in the Torres Strait Islands, located between Australia and New Guinea, investigators identified a strong positive correlation between urinary markers of Cd exposure and diabetic nephropathy [204]. Similarly, a cross-sectional study of 1699 Belgium subjects suggested that diabetic patients may be more susceptible to the nephrotoxic effects of Cd [205]. Moreover, Åkesson and colleagues assessed the effect of Cd exposure on diabetes-induced renal dysfunction in 10,766 subjects and reported that the nephrotoxic effects of $\mathrm{Cd}$ exposure could be observed at lower levels in diabetic patients compared with non-diabetic patients [138].

Interestingly, $\mathrm{Cd}$ levels in men and women appear to differ significantly. The body burden of $\mathrm{Cd}$ in women tends to be significantly greater than that in men. In a study of healthy Thai men and women, it was found that the average urinary excretion of $\mathrm{Cd}$ in non-smoking women was similar to that of men who smoked cigarettes [206]. In a study carried out in 57 non-smoking women, it was found that 
urinary and blood levels of cadmium correlated with age and body iron stores [207]. Women with lower serum ferritin were found to have higher levels of Cd [207,208]. In general, women have lower iron stores than men; when iron stores are low, the divalent metal transporter 1 (DMT1) in the intestine is upregulated to facilitate increased intestinal uptake of ferrous iron $\left(\mathrm{Fe}^{2+}\right)$ [209]. DMT1 has also been shown to mediate the intestinal uptake of Cd [209,210]; therefore, upregulation of this carrier could potentially increase the absorption of dietary $\mathrm{Cd}$ ions from the lumen of the intestine. Indeed, it has been proposed that an increase in DMT1 expression and consequent increase in Cd absorption is the primary reason for the greater levels of Cd detected in women [206-208].

\subsection{Lead}

Lead $(\mathrm{Pb})$ is a toxic metal that usually exists bound to two or more other compounds. $\mathrm{Pb}$ is found throughout the environment, which is primarily due to various human activities. Pb compounds were found commonly in gasoline, batteries, pipes, and ammunition. In addition, $\mathrm{Pb}$ compounds were once used frequently as pigment in paints and ceramic glazes. When leaded gasoline was used as the primary source of fuel for automobiles, the environment became contaminated heavily with large quantities of $\mathrm{Pb}$. In addition, the paint in many homes was Pb-based, containing up to $40 \% \mathrm{~Pb}$ [14]. Water pipes in older homes and water systems may contain $\mathrm{Pb}$ solder, which may leach into the water supply and lead to significant exposure to $\mathrm{Pb}$ compounds [211-213].

Occupational exposure to the inorganic form of $\mathrm{Pb}\left(\mathrm{Pb}^{2+}\right)$ can occur through welding processes, in the manufacture of $\mathrm{Pb}$-containing batteries, lead smelting and refining, and in the production of pottery [14]. Of particular concern is the exposure of children to $\mathrm{Pb}^{2+}$, which occurs primarily via the ingestion of contaminated soil [14]. It is estimated that a large percentage of adults and children in the United States have blood lead levels that are higher than that which is considered to be safe [214-216].

$\mathrm{Pb}$ has been shown to have serious consequences on the nervous, circulatory, skeletal, renal, hematopoietic, and endocrine systems [14,217]. Pb poisoning is more common in children than adults are and is characterized by neurological symptoms such as headache, convulsions, ataxia, learning disorders, and hyperactive behavior [218]. Exposure to $\mathrm{Pb}$ may also result in nephropathy, renal adenocarcinoma, cardiovascular disease, and metabolic defects in bone $[14,217,219]$.

\subsubsection{Renal Handling of Lead}

Despite the nephropathy caused by exposure to $\mathrm{Pb}$ compounds, the mechanisms by which $\mathrm{Pb}$ enters target cells in the kidney are not well understood. Several mechanisms have been postulated to explain the transport of $\mathrm{Pb}^{2+}$ into and out of target cells (Table 3).

Table 3. Potential mechanisms involved in the renal tubular transport of lead.

\begin{tabular}{ccc}
\hline & Transport Mechanism & Species \\
\hline Apical uptake & $\begin{array}{c}\text { Receptor-mediated endocytosis } \\
\mathrm{Ca}^{2+} \text { channels }\end{array}$ & $\begin{array}{c}\text { Pb-protein complexes } \\
\mathrm{Pb}^{2+}\end{array}$ \\
\hline Basolateral uptake & $?$ & $?$ \\
\hline Apical export & $\mathrm{MRP2}$ & $\mathrm{GSH}-\mathrm{Pb}$ \\
& $\mathrm{BCRP}$ & $\mathrm{GSH}-\mathrm{Pb}$ \\
\hline Basolateral export & $\mathrm{Ca}^{2+}$-ATPase & $\mathrm{Pb}^{2+}$ \\
\hline MRP: multidrug resistance-associated protein; BCRP: breast cancer resistance protein.
\end{tabular}

Endocytosis of $\mathrm{Pb}^{2+}$-protein complexes may serve as a route for the entry of this metal into cells [220]. Initially, a $63 \mathrm{KDa}$ protein was identified as a $\mathrm{Pb}^{2+}$-binding protein (PbBP) in the cytosolic fraction of rat kidneys [221,222]. This protein was identified later as alpha-2-microglobulin [223,224]. Subsequent studies identified diazapine-binding inhibitor (DBI) and thymosin $\beta-4$ as additional PbBPs found in the kidney [220]. 
In addition, numerous in vivo and in vitro studies have described an interaction between $\mathrm{Pb}$ and $\mathrm{Ca}^{2+}$, suggesting that $\mathrm{Pb}^{2+}$ may utilize $\mathrm{Ca}^{2+}$ channels in order to gain entry into cells [225-227]. Additional studies suggest that the absorption of $\mathrm{Pb}^{2+}$ is inversely proportional to dietary levels of $\mathrm{Ca}^{2+}$ [228-231]. Indeed, an examination of approximately 3,000 children that were exposed to $\mathrm{Pb}^{2+}$ also revealed a relationship between dietary $\mathrm{Ca}^{2+}$ and blood levels of $\mathrm{Pb}$ [232]. It appears that low dietary intake of $\mathrm{Ca}^{2+}$ can lead to higher levels of $\mathrm{Pb}^{2+}$ in blood. The reverse of this relationship was also shown in that high intake of $\mathrm{Ca}^{2+}$ was associated with lower blood levels of $\mathrm{Pb}^{2+}[231,233,234]$. Owing to the interaction between $\mathrm{Pb}^{2+}$ and $\mathrm{Ca}^{2+}$, it can be hypothesized that $\mathrm{P}^{+}$enters cells through one or more $\mathrm{Ca}^{2+}$ channels. Moreover, since the atomic radius of $\mathrm{Pb}(1.81 \AA)$ is smaller than that of $\mathrm{Ca}^{2+}(2.23 \AA)$, it is possible that $\mathrm{Pb}$ may act as a mimic of $\mathrm{Ca}^{2+}$ at the site of $\mathrm{Ca}^{2+}$ transporters.

Reabsorption of $\mathrm{Ca}^{2+}$ by proximal tubules is a two-step process with $\mathrm{Ca}^{2+}$ channels mediating the transport across the apical membrane and a $\mathrm{Ca}^{2+}$-ATPase on the basolateral membrane that mediates the movement of $\mathrm{Ca}^{2+}$ across the basolateral membrane [235]. $\mathrm{Pb}^{2+}$ appears to gain access to proximal tubular cells via $\mathrm{Ca}^{2+}$ channels on the apical membrane [236-239]. Studies in several different cell-types, including HEK293 cells, a human embryonic kidney cell-line, demonstrated that $\mathrm{Pb}^{2+}$ can enter cells via store-operated calcium channels (SOCs) $[236,239,240]$. It appears that Orai1 and stromal interacting protein 1 (STIM1), which are critical components of SOCs, play important roles in the cellular entry of $\mathrm{Pb}^{2+}$ [241]. Data from these studies also indicate that the flux of $\mathrm{Pb}$ through $\mathrm{Ca}^{2+}$ channels is a timeand concentration-dependent process and is approximately tenfold greater than that observed for $\mathrm{Ca}^{2+}$. Exit of $\mathrm{Ca}^{2+}$ at the basolateral membrane involves a $\mathrm{Ca}^{2+}$-ATPase. In vivo studies using erythrocytes indicate that $\mathrm{Pb}$ may substitute for $\mathrm{Ca}^{2+}$ at the site of the $\mathrm{Ca}^{2+}$-ATPase $[237,242]$. The ability of $\mathrm{Pb}$ to be transported by the $\mathrm{Ca}^{2+}$-ATPase in proximal tubular cells has not been shown; however, since the $\mathrm{Ca}^{2+}$-ATPase is homologous across cell-types, it is feasible to suggest that this transporter may mediate the movement of $\mathrm{Pb}$ across the basolateral membrane of proximal tubular cells.

$\mathrm{Pb}$ may also be transported out of at the apical membrane of proximal tubular cells into the lumen for eventual excretion in the urine. Experiments in rats suggest that $\mathrm{Pb}$ can be transported out of cells as a conjugate of GSH [243]. Though the transport of a GSH- $\mathrm{Pb}^{2+}$ complex was not demonstrated directly, it is possible that this complex may be a transportable form of $\mathrm{Pb}$ at the site of a transporter such as MRP2 or BCRP. These carriers are localized in the apical membrane of proximal tubular cells and mediate the export of a wide variety of compounds [52]; therefore, it is possible that MRP2 and BCRP may mediate the export of GSH-Pb complexes.

\subsubsection{Renal Effects of Lead Exposure}

Owing to the role of the kidney in urinary excretion of toxicants, the kidney appears to be one of the primary sites of accumulation of $\mathrm{Pb}$ [244]. Exposure to low levels of $\mathrm{Pb}$ early in life have been shown to lead to glomerular hypertrophy, manifested specifically as an increase in the volume of glomerular capillaries [245]. Exposure to $\mathrm{Pb}$ may disrupt glomerular development which may result in renal insufficiency later in life. The tubules are also affected by exposure to $\mathrm{Pb}$. Acute exposure can lead to generalized defects in solute and amino acid transport in renal tubules, leading to a Fanconi syndrome $[225,246,247]$. Chronic exposure to $\mathrm{Pb}$ may lead to progressive tubulointerstitial nephritis that is characterized by infiltration of leukocytes, interstitial fibrosis, and tubular atrophy [248]. Similarly, when Wistar rats were exposed to lead acetate, tubular degeneration, intraluminal hyaline casts, blood vessel congestion, perivascular fibrosis, and vascular edema were observed [249]. Since $\mathrm{Pb}$ tends to induce injury in proximal tubules, kidney injury molecule-1 (KIM1) [250] and alpha-glutathione $S$-transferase ( $\alpha \mathrm{GST}$ ) [251] appear to be appropriate urinary biomarkers for $\mathrm{Pb}$-induced renal injury.

One of the primary cellular effects of exposure to $\mathrm{Pb}$ is the induction of oxidative stress in the cells of the kidney [252,253]. Exposure of mice to lead acetate enhances the production of reactive oxygen species and reduces the mRNA expression of enzymes necessary to counteract oxidative stress (i.e., catalase, superoxide dismutase, glutathione $S$-transferase, glutathione peroxidase). Alternatively, 
exposure of mice to $\mathrm{Pb}$ enhanced mRNA expression of transforming growth factor- $\beta 1$ (TGF $\beta 1$ ), monocyte chemoattractant protein-1 (MCP-1), and alpha-2 macroglobulin $(\alpha-2 \mathrm{M})$, which lead to inflammatory processes [249]. Exposure to $\mathrm{Pb}$ has also been shown to lead to lipid oxidation and DNA fragmentation [254].

It appears that mitochondria play an important role in $\mathrm{Pb}$-mediated injury. Oxidative stress within the cell may lead to alterations in the regulation of the mitochondria permeability transition pore (MPTP) [255], which normally mediates the osmotic influx of water into the mitochondrial matrix [256]. Exposure of cells to $\mathrm{Pb}$ has been shown to induce abnormal opening of the MPTP which leads to swelling of mitochondria, changes in membrane potential, and initiation of apoptosis [253,256-258]. Exposure of cells to $\mathrm{Pb}$ also leads to structural alterations in the mitochondria such as distortion of the mitochondrial cristae and swelling and rupture of the outer membrane [255].

$\mathrm{Pb}$, like the cationic species of some of the other toxic metals, is also capable of acting as a functional mimic of endogenous ions at intracellular binding sites. It has been shown to be a functional substitute for $\mathrm{Ca}^{2+}$ at the site of calmodulin $[259,260]$, a protein that plays a role in the regulation of intracellular $\mathrm{Ca}^{2+}$ [261]. In addition, the activity of protein kinase C (PKC) may be affected by the binding of $\mathrm{Pb}$. Under normal conditions, $\mathrm{Ca}^{2+}$ activates PKC, which mediates numerous intracellular processes and signaling cascades. Interestingly, it has been reported that $\mathrm{Pb}$ is a better activator of protein kinase $\mathrm{C}$ than is $\mathrm{Ca}^{2+}$ [227]. It is important to note that the actions of intracellular $\mathrm{Ca}^{2+}$, unlike $\mathrm{Pb}$, are highly regulated. Therefore, the binding of $\mathrm{Pb}^{2+}$ to an enzyme such as protein kinase $\mathrm{C}$ may activate the enzyme unnecessarily and result in deleterious effects. $\mathrm{Pb}$ may also act as a mimic of $\mathrm{Ca}^{2+}$ at binding sites of cellular junctions. Many junctional complexes require $\mathrm{Ca}^{2+}$ in order to maintain their integrity and, thus, binding of $\mathrm{Pb}$ instead of $\mathrm{Ca}^{2+}$ may compromise the integrity of the junctional complex.

In addition, exposure to $\mathrm{Pb}$ has been shown to alter the subcellular distribution of calcium in renal cells [262]. Specifically, exposure to $\mathrm{Pb}$ resulted in elevated levels of calcium in the cytoplasm and mitochondria while calcium levels in the endoplasmic reticulum were depleted. These changes in intracellular calcium ratios may lead to significant alterations in intracellular signaling pathways and eventual apoptosis [262]. Interestingly, administration of the calcium channel blockers, verapamil and nimodipine, have been shown to decrease lipid oxidation and increase the activities of superoxide dismutase and glutathione peroxidase [263].

\subsubsection{CKD and the Effects of Lead Exposure on the Kidneys}

Although it was once thought that exposure to $\mathrm{Pb}$ was not directly associated with renal disease [264], it appears that there may be a direct relationship between exposure to $\mathrm{Pb}$ and the development of kidney disease [265-267]. A study of industrial workers exposed occupationally to $\mathrm{Pb}$ did not detect overt signs of renal dysfunction. However, analyses of biochemical markers in urine suggested that $\mathrm{Pb}$ induces changes at the cellular level even if renal function is not compromised [248]. Not surprisingly, individuals with higher blood $\mathrm{Pb}$ concentrations have a higher risk of renal injury [268]. A cross-sectional study of individuals in Mexico suggested that serum creatinine levels correlate positively with blood $\mathrm{Pb}$ [269]. This finding provides some indication that exposure to $\mathrm{Pb}$ may lead to a reduction in GFR. Similarly, a cross-sectional study of Korean adults demonstrated a positive correlation between blood $\mathrm{Pb}$ levels and renal dysfunction [270]. Additionally, erythrocyte $\mathrm{Pb}$ appears to be associated with renal injury [271].

\subsection{Mercury}

Mercury is a toxic metal found in many environmental and industrial settings. It exists in elemental (metallic), inorganic, and/or organic forms. Elemental mercury $\left(\mathrm{Hg}^{0}\right)$ is unique in that it exists as a liquid at room temperature. Inorganic mercury may be found as mercurous $\left(\mathrm{Hg}^{1+}\right)$ or mercuric $\left(\mathrm{Hg}^{2+}\right)$ ions, which are usually bound to chlorine, sulfur, or oxygen to form mercurous or mercuric salts. There are several common forms of organic mercury such as phenylmercury, dimethylmercury, and monomethylmercury. Of these forms, methylmercury $\left(\mathrm{CH}_{3} \mathrm{Hg}^{+}\right)$is encountered 
most frequently in the environment. It is formed predominantly when inorganic mercuric ions are methylated by microorganisms present in soil and water [272-275].

Humans are exposed to mercuric compounds via occupational, environmental, and dietary sources $[272,273,275,276]$. The majority of human exposure is due to the ingestion of food contaminated with $\mathrm{CH}_{3} \mathrm{Hg}^{+}$. Upon ingestion, $\mathrm{CH}_{3} \mathrm{Hg}^{+}$is absorbed readily by the gastrointestinal tract of humans and other mammals [272]. Mercuric ions can then enter systemic circulation where they can be delivered to target organs. It is important to note that approximately 14 days after exposure to $\mathrm{CH}_{3} \mathrm{Hg}^{+}$, a fraction of absorbed $\mathrm{CH}_{3} \mathrm{Hg}^{+}$may be oxidized to form $\mathrm{Hg}^{2+}$ [277-281].

\subsubsection{Renal Handling of Mercury}

Inorganic and organic forms of mercury accumulate readily in the kidney. The kidney is the primary site of accumulation of and intoxication by inorganic forms of mercury. The accumulation of $\mathrm{Hg}^{2+}$ in renal tubular cells, primarily those of the proximal tubule, occurs rapidly with approximately $50 \%$ of a nontoxic dose found in the kidneys after a few hours of exposure $[275,282]$. Organic forms of mercury, which primarily affect the central nervous system, may also have serious toxicological effects in the kidney [283-286]. It is important to note that within biological systems, mercurous, mercuric, or methylmercuric ions do not exist as inorganic salts, or in an unbound, "free" ionic state [287]. Rather, mercuric ions are bound to one or more thiol-containing biomolecules, such as GSH, Cys, Hcy, $\mathrm{N}$-acetylcysteine (NAC), and albumin. For $\mathrm{Hg}^{2+}$, this bonding occurs in a linear II, coordinate covalent manner while thiol-conjugates of $\mathrm{CH}_{3} \mathrm{Hg}^{+}$form linear I, coordinate covalent complexes $[288,289]$.

At the cellular level, mercuric ions appear to gain access to proximal tubular cells via mechanisms present in the luminal and basolateral plasma membranes (Table 4) [290-294]. In vitro studies utilizing isolated perfused proximal tubules suggest that a Cys S-conjugate of $\mathrm{Hg}^{2+}$ (Cys-S-Hg-S-Cys) is the primary form of $\mathrm{Hg}^{2+}$ transported across the luminal membrane of proximal tubular cells [295-297]. Additional studies indicate that amino acid transporters located in the luminal plasma membrane are likely involved in the uptake of mercuric conjugates from the tubular lumen [290,291]. It has been hypothesized that since Cys-S-Hg-S-Cys is similar in size and shape to the amino acid cystine, this mercuric conjugate may be a substrate of a cystine transporter. Studies using Madin-Darby Canine Kidney (MDCK) cells transfected with the sodium-independent cystine transporter, system $\mathrm{b}^{0,+}$, provide strong evidence implicating this carrier in the cellular uptake of Cys-S-Hg-S-Cys [298]. Similar studies have also identified the Hcy $S$-conjugate of $\mathrm{Hg}$ (Hcy-S-Hg-S-Hcy) as a substrate for system $b^{0,+}$ [299]. Furthermore, evidence from studies in Xenopus laevis oocytes suggests that Cys- and Hcy-S-conjugates of $\mathrm{CH}_{3} \mathrm{Hg}^{+}$(Cys-S- $\mathrm{CH}_{3} \mathrm{Hg}^{+}$and $\mathrm{Hcy}-\mathrm{S}_{-} \mathrm{CH}_{3} \mathrm{Hg}^{+}$, respectively) are substrates of the sodium-dependent amino acid carrier, system $\mathrm{B}^{0,+}[300]$. Currently, there are no data supporting a role for system $\mathrm{B}^{0,+}$ in the uptake of Cys-S-Hg-S-Cys or Hcy-S-Hg-S-Hcy [300].

Table 4. Potential mechanisms involved in the renal tubular transport of mercury.

\begin{tabular}{|c|c|c|}
\hline & Transport Mechanism & Species \\
\hline Apical uptake & $\begin{array}{l}\text { System } b^{0,+} \\
\text { System } \mathrm{B}^{0,+}\end{array}$ & $\begin{array}{l}\text { Cys- and Hcy-S-conjugates of } \mathrm{Hg}^{2+} \\
\text { Cys-S-conjugates of } \mathrm{MeHg}\end{array}$ \\
\hline Basolateral uptake & $\begin{array}{l}\text { OAT1 } \\
\text { OAT3 }\end{array}$ & $\begin{array}{l}\text { Cys-, Hcy-, NAC-S-conjugates of } \mathrm{Hg}^{2+} \text { and } \mathrm{MeHg} \\
\text { Cys-S-conjugates of } \mathrm{Hg}^{2+}\end{array}$ \\
\hline Apical export & $\begin{array}{l}\text { MRP2 } \\
\text { BCRP }\end{array}$ & $\begin{array}{c}\text { DMPS-, DMSA-, NAC-S-conjugates of } \mathrm{Hg}^{2+} \\
\text { DMPS-, DMSA-S-conjugates of } \mathrm{MeHg}^{2} \\
\text { DMPS- and Cys-S-conjugates of } \mathrm{Hg}^{2+}\end{array}$ \\
\hline Basolateral export & $?$ & $?$ \\
\hline
\end{tabular}


Approximately $40-60 \%$ of the mercury that accumulates in proximal tubular cells is taken up at the basolateral plasma membrane [292,294,297,301-304]. Numerous in vitro studies using cultured MDCK cells stably transfected with the organic anion transporter, OAT1 (SLC22A6), provide strong evidence indicating that mercuric conjugates of Cys, Hcy, and NAC (NAC-S-Hg-S-NAC) are taken up by this carrier [305-315]. Cys-S-Hg-S-Cys has also been shown to be a transportable substrate of OAT3 [316]. Both, OAT1 and OAT3 (SLC22A8) are localized in the basolateral plasma membrane of proximal tubular epithelial cells $[307,308]$. Based on current scientific knowledge, it appears that OAT1 is the primary mechanism involved in the basolateral transport of Cys-S-Hg-S-Cys, NAC-S-Hg-S-NAC, and Hcy-S-Hg-S-Hcy into proximal tubular cells [292,293,297,301-304,316-318]. In addition to conjugates of $\mathrm{Hg}^{2+}$, Cys-, NAC-, and $\mathrm{Hcy}-\mathrm{S}$-conjugates of $\mathrm{CH}_{3} \mathrm{Hg}^{+}$have also been identified as substrates for OAT1 [313-315]. Collectively, these data provide strong support for a role of OAT1 and OAT3 in the basolateral uptake of certain mercuric complexes.

Once mercuric ions gain access to the intracellular compartment of cells, they form strong bonds with protein and non-protein thiol-containing biomolecules. Intracellular mercuric ions also stimulate, and bind to, MT and/or GSH $[319,320]$. Binding to these biomolecules often prevents or reduces greatly the export of mercuric ions from the cell. It is well-documented that mercuric ions can be extracted from renal tubular cells following treatment with a metal chelating agent, such as 2,3-bis(sulfanyl)propane-1-sulfonic acid (formally known as 2,3-dimercaptopropane-1-sulfonic acid; DMPS) [321] or 2,3-dimercaptosuccinic acid (DMSA) [321-327]. It appears that DMPS and DMSA gain access to proximal tubular cells at the basolateral membrane via OAT1, OAT3 and/or the sodium-dependent dicarboxylate transporter ( $\mathrm{NaC2}$ ) [328-331]. Once inside the cell, it is hypothesized that DMPS and DMSA form complexes with intracellular $\mathrm{Hg}^{2+}$ and / $\mathrm{or} \mathrm{CH}_{3} \mathrm{Hg}^{+}$and that these complexes are then exported across the luminal membrane via MRP2 or BCRP [332-335]. Interestingly, NAC also appears to mediate the extraction of mercuric ions following exposure of rats to $\mathrm{CH}_{3} \mathrm{Hg}^{+}[336,337]$. Collectively, these data provide solid evidence for the hypothesis that MRP2 plays an important role in the renal elimination of mercuric ions following exposure to forms of $\mathrm{Hg}^{+2}$ or $\mathrm{CH}_{3} \mathrm{Hg}^{+}$.

\subsubsection{Renal Effects of Mercury Exposure}

Exposure to all forms of mercury can have nephrotoxic effects [283-286]; however exposure to conjugates of $\mathrm{Hg}^{2+}$ leads to the most severe nephropathy. The pars recta of the proximal tubule appears to be the most sensitive to the toxic effects of mercury and is usually the first segment of the nephron affected by exposure to mercuric compounds [275]. The pars convoluta and distal segments of the nephron are not usually affected by exposure to low doses of mercury, but exposure to higher doses can lead to injury and necrosis in these segments [338-340]. Electron microscopic analyses of $\mathrm{Hg}$-induced toxicological changes documented early alterations in mitochondrial structure and the presence of pyknotic nuclei. Approximately six hours after exposure, cells begin to lose microvilli, mitochondrial swelling worsens, and dilation of the endoplasmic reticulum can be detected [338]. Reductions in enzymatic activity in the pars recta have also been described [339]. Twelve hours after exposure to $\mathrm{HgCl}_{2}$, electron microscopic analyses of cells revealed rupture of the plasma membrane, loss of microvilli, decreased contact with the basement membrane, and destruction of cell shape [341]. After $24 \mathrm{~h}$, cellular fragments can be identified in the tubular lumen, junctional complexes between cells are absent, and nuclear structure is compromised [339-341]. When tubular epithelial cells are injured and die, numerous brush-border and intracellular enzymes, such as alkaline phosphatase, $\gamma$-glutamyltransferase, lactate dehydrogenase, aspartate aminotransferase (AST), and alanine aminotransferase (ALT), can be identified in urine [325,342-346]. As the extent of mercury-induced renal injury progresses, there is also a simultaneous increase in the urinary excretion of mercuric species [347-349].

Exposure to $\mathrm{HgCl}_{2}$ can also have detrimental effects on glomeruli. Chronic exposure of rats to a non-nephrotoxic dose of $\mathrm{HgCl}_{2}$ led to tubular, interstitial, and glomerular lesions [350]. Similarly, 
in rats exposed chronically to methylmercury, fibrotic changes were observed in glomeruli, and deposits of IgG, IgM, and C3 were detected along the glomerular basement membrane [351]. Furthermore, an analysis of data from patients exposed chronically to mercuric compounds indicates that exposure to mercury can lead to glomerular injury and disease [352]. Collectively, these studies suggest that chronic exposure to $\mathrm{Hg}^{2+}$ or $\mathrm{CH}_{3} \mathrm{Hg}^{+}$may lead to the development of membranous glomerulonephritis. Glomerular alterations such as fibrosis and glomerulonephritis often lead to reductions in GFR. Thus, it is not surprising that reductions in GFR have been observed after exposure to mercuric compounds [338,353].

\subsubsection{CKD and the Effects of Mercury Exposure on the Kidney}

Although individuals with CKD make up a significant percentage of the population, and exposure to mercury and mercuric compounds is an important environmental problem, the information about the relationship between diseased kidneys and the effects of mercury exposure remains sparse. Considering the lack of epidemiological studies related to the exposure of patients with CKD to mercury, the current review will focus on experimental studies using models of reduced renal mass and CKD.

There is not an animal model that perfectly mimics the renal and systemic changes that occur as part of CKD. However, the decline in functional renal mass that occurs in patients with CKD is similar to an experimental model in which animals are $50 \%$ or $75 \%$ nephrectomized. Although the nephrectomized rat models are not exact mimics of CKD, similarities exist between these systems. In each, a significant number of nephrons are lost and remaining nephrons must go through a compensatory, hypertrophic phase in order to maintain normal fluid and solute homeostasis $[3,9,190]$. Hyperfiltration, hyperperfusion, and an increase in the levels of certain proteins occur in hypertrophied nephrons. These changes may lead to these nephrons being exposed to higher levels of nephrotoxicants such as mercury, which may enhance the susceptibility of these nephrons to the harmful effects of mercury or other nephrotoxicants [345,354-361].

Studies using 50\% nephrectomized rats as models of the early stages of CKD indicate that acute renal failure was more pronounced in nephrectomized rats exposed to a nephrotoxic dose of $\mathrm{HgCl}_{2}$ than in corresponding sham rats $[345,354,356]$. Exposure to $\mathrm{HgCl}_{2}$ led to glomerular and tubular dysfunction, which appeared to be more severe in 50\% nephrectomized rats than in sham rats [354]. It was found that mercury-induced proximal tubular necrosis was more extensive in $50 \%$ nephrectomized animals than in sham animals. Additionally, the urinary excretion of cellular enzymes and plasma proteins, including lactate dehydrogenase, $\gamma$-glutamyltransferase and albumin, was greater in $50 \%$ nephrectomized animals than in sham animals [13,345].

The use of $75 \%$ nephrectomized rats as models of CKD facilitates the study of a later stage of disease. The handling of mercury in these rats is significantly different than that in $50 \%$ nephrectomized or sham rats. Since the GFR of these rats is reduced significantly, total renal accumulation of mercury is significantly lower than in 50\% nephrectomized or sham rats. However, the accumulation of mercury per $g$ kidney is significantly greater in $75 \%$ nephrectomized rats than in shams, suggesting that the mercury uptake into individual cells may be greater in the remnant renal mass from $75 \%$ nephrectomized animals than in kidneys of sham animals [362]. It is also notable that the expression of mRNA encoding OAT1 and MRP2 also increased in the remnant renal mass of $75 \%$ nephrectomized rats. The enhanced expression of these carriers may be the underlying cause of the increased uptake of mercury into renal cells of the $75 \%$ nephrectomized rat [362]. Indeed, exposure of $75 \%$ nephrectomized rats to $\mathrm{HgCl}_{2}$ leads to renal injury that is more extensive and severe than that in corresponding sham rats (Figure 2). 

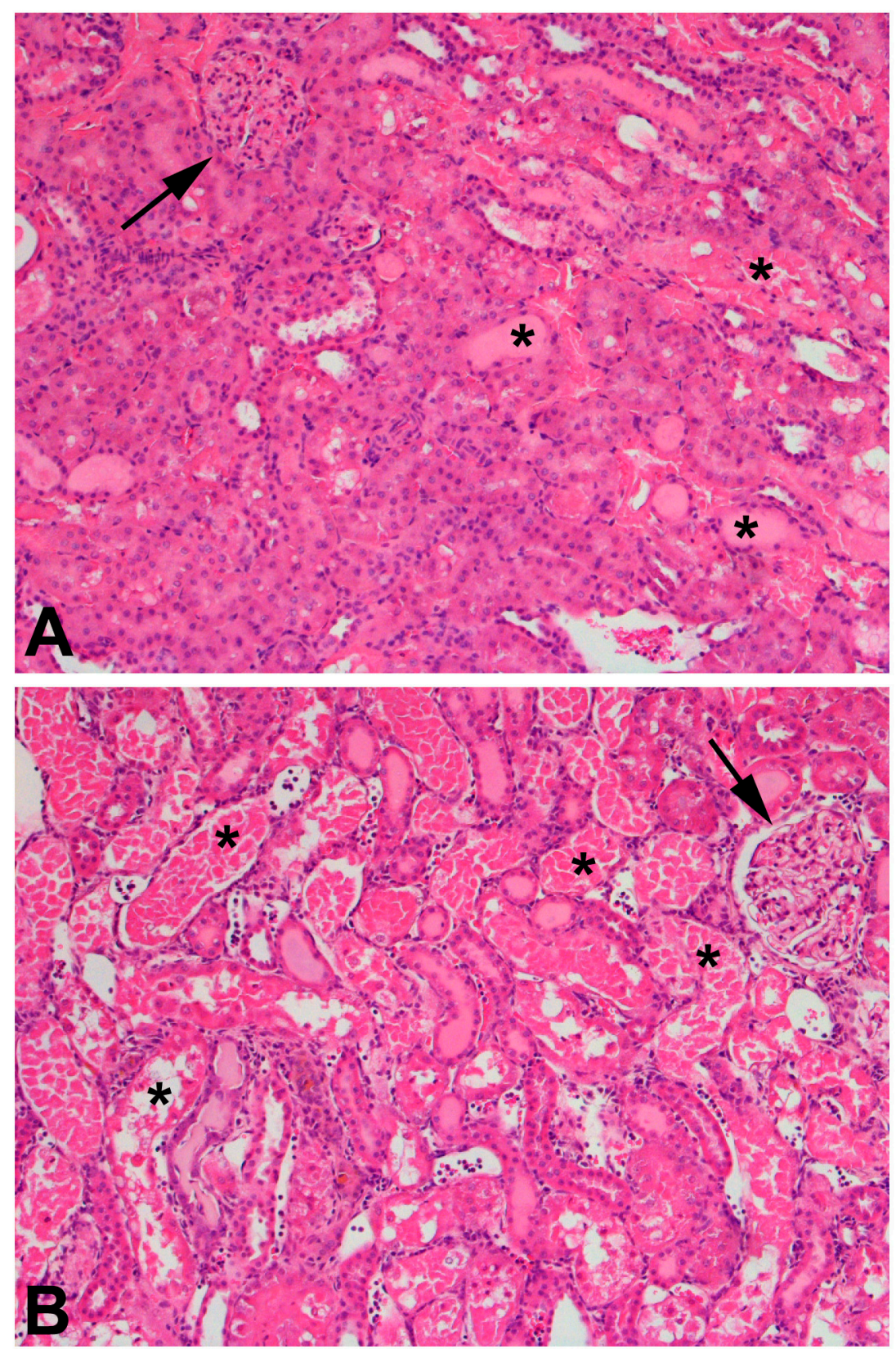

Figure 2. Histological sections of kidneys from Sham or 75\% nephrectomized Wistar rats exposed to $2.5 \mu \mathrm{mol} \mathrm{kg}{ }^{-1} \mathrm{HgCl}_{2}$. Panel (A) shows a representative section of kidney from Sham rats exposed to $2.5 \mu \mathrm{mol} \mathrm{kg}{ }^{-1} \mathrm{HgCl}_{2}$. This section displays a normal glomerulus (arrow) and a mix of normal and injured tubules $\left(^{*}\right)$. In addition, there is an infiltration of lymphocytes, which is likely one of the first responses to the inflammation caused by exposure to mercury. Panel (B) shows a representative section of kidney from $75 \%$ nephrectomized rats exposed to $2.5 \mu \mathrm{mol} \mathrm{kg}{ }^{-1} \mathrm{HgCl}_{2}$. Glomeruli (arrows) were hypertrophied and tubular necrosis $\left(^{*}\right)$ was widespread. The degree of injury in the $75 \%$ nephrectomized rats was significantly greater than that in corresponding Sham rats, suggesting that rats with reduced renal mass may be more sensitive to the nephrotoxicants such as mercury, than rats with normal renal mass. Magnification, $100 \times$.

Collectively, the results of these studies suggest that kidneys of animals with reduced renal mass are more susceptible to the toxic effects of mercury. Similarly, individuals who have reduced renal function, due to CKD or other disease processes, may be more susceptible to renal injury following exposure to a nephrotoxicant such as mercury. 


\section{Summary}

CKD has been well-studied and the structural and functional changes that are associated with it have been characterized extensively. However, there is little information regarding the response of injured kidneys to environmental toxicants such as arsenic, cadmium, lead, or mercury. Because of the prevalence of these metals in the environment, human exposure to one or more of these metals is nearly unavoidable. Furthermore, it is well-known that acute and chronic exposures to one or a combination of these toxic metals can be detrimental to the kidneys of normal adults. Therefore, it can be postulated that exposure of CKD patients to these metals may lead to additional reductions in renal function. Individuals with compromised renal function are especially susceptible to nephrotoxicants. The few studies available have demonstrated an association between exposure to heavy metals and an increase in the incidence and severity of renal disease. It is important to note that early signs of renal dysfunction often go unnoticed, thus, individuals with reduced renal function are often unaware that they are at risk during the early stages of disease [363,364]. Exposure to one or more nephrotoxicants (such as heavy metals) may occur during this early period and this exposure may be especially detrimental to these individuals in that it may enhance morbidity and/or mortality. Therefore, a thorough and complete understanding of the way in which nephrotoxicants are handled by dysfunctional kidneys is of utmost importance. Because of the paucity of data available on this topic, additional studies are clearly necessary.

Acknowledgments: Supported by NIH grant ES019991 awarded to Christy C. Bridges.

Conflicts of Interest: The authors declare no conflict of interest.

\section{References}

1. Price, R.G. Urinary enzymes, nephrotoxicity and renal disease. Toxicology 1982, 23, 99-134. [CrossRef]

2. Zalups, R.K.; Diamond, G.L. Mercuric chloride-induced nephrotoxicity in the rat following unilateral nephrectomy and compensatory renal growth. Virchows Arch. B Cell Pathol. Incl. Mol. Pathol. 1987, 53, 336-346. [CrossRef] [PubMed]

3. Zalups, R.K.; Cox, C.; Diamond, G.L. Histological and urinalysis assessment of nephrotoxicity induced by mercuric chloride in normal and uninephrectomized rats. In Biological Monitoring of Toxic Metals; Clarkson, T.W., Friberg, L., Nordberg, G.F., Sager, P.R., Eds.; Plenum Publishing Corporation: New York, NY, USA, 1988; pp. 531-545.

4. Clarkson, T.W.; Magos, L. The effect of sodium maleate on the renal deposition and excretion of mercury. Br. J. Pharmacol. Chemother. 1967, 31, 560-567. [CrossRef] [PubMed]

5. Magos, L.; Stoytchev, T. Combined effect of sodium maleate and some thiol compounds on mercury excretion and redistribution in rats. Br. J. Pharmacol. 1969, 35, 121-126. [CrossRef] [PubMed]

6. Trojanowska, B.; Piotrowski, J.K.; Szendzikowski, S. The influence of thioacetamide on the excretion of mercury in rats. Toxicol. Appl. Pharmacol. 1971, 18, 374-386. [CrossRef]

7. Hall, R.L.; Wilke, W.L.; Fettman, M.J. Renal resistance to mercuric chloride toxicity during prolonged exposure in rats. Vet. Hum. Toxicol. 1986, 28, 305-307. [PubMed]

8. Eto, K.; Yasutake, A.; Miyamoto, K.; Tokunaga, H.; Otsuka, Y. Chronic effects of methylmercury in rats. II. Pathological aspects. Tohoku J. Exp. Med. 1997, 182, 197-205. [CrossRef] [PubMed]

9. Miller, S.; Pallan, S.; Gangji, A.S.; Lukic, D.; Clase, C.M. Mercury-associated nephrotic syndrome: A case report and systematic review of the literature. Am. J. Kidney Dis. 2013, 62, 135-138. [CrossRef] [PubMed]

10. Vanholder, R.C.; Praet, M.M.; Pattyn, P.A.; Leusen, I.R.; Lameire, N.H. Dissociation of glomerular filtration and renal blood flow in $\mathrm{HgCl}$-induced acute renal failure. Kidney Int. 1982, 22, 162-170. [CrossRef] [PubMed]

11. Houser, M.T.; Berndt, W.O. The effect of unilateral nephrectomy on the nephrotoxicity of mercuric chloride in the rat. Toxicol. Appl. Pharmacol. 1986, 83, 506-515. [CrossRef]

12. Houser, M.T.; Berndt, W.O. Unilateral nephrectomy in the rat: Effects on mercury handling and renal cortical subcellular distribution. Toxicol. Appl. Pharmacol. 1988, 93, 187-194. [CrossRef] 
13. Ramos-Frendo, B.; Perez-Garcia, R.; Lopez-Novoa, J.M.; Hernando-Avendano, L. Increased severity of the acute renal failure induced by $\mathrm{HgCl} 2$ on rats with reduced renal mass. Biomedicine 1979, 31, 167-170. [PubMed]

14. Zalups, R.K. Autometallographic localization of inorganic mercury in the kidneys of rats: Effect of unilateral nephrectomy and compensatory renal growth. Exp. Mol. Pathol. 1991, 54, 10-21. [CrossRef]

15. Zalups, R.K. Enhanced renal outer medullary uptake of mercury associated with uninephrectomy: Implication of a luminal mechanism. J. Toxicol. Environ. Health 1997, 50, 173-194. [CrossRef] [PubMed]

16. Zalups, R.K.; Barfuss, D.W.; Kostyniak, P.J. Altered intrarenal accumulation of mercury in uninephrectomized rats treated with methylmercury chloride. Toxicol. Appl. Pharmacol. 1992, 115, 174-182. [CrossRef]

17. Zalups, R.K.; Klotzbach, J.M.; Diamond, G.L. Enhanced accumulation of injected inorganic mercury in renal outer medulla after unilateral nephrectomy. Toxicol. Appl. Pharmacol. 1987, 89, 226-236. [CrossRef]

18. Bridges, C.C.; Barfuss, D.W.; Joshee, L.; Zalups, R.K. Compensatory Renal Hypertrophy and the Uptake of Cysteine S-Conjugates of $\mathrm{Hg}^{2+}$ in Isolated S2 Proximal Tubular Segments. Toxicol. Sci. 2016, 154, 278-288. [CrossRef] [PubMed]

19. Zalups, R.K.; Bridges, C.C. Seventy-five percent nephrectomy and the disposition of inorganic mercury in 2,3-dimercaptopropanesulfonic acid-treated rats lacking functional multidrug-resistance protein 2. J. Pharmacol. Exp. Ther. 2010, 332, 866-875. [CrossRef] [PubMed]

20. Centers for Disease Control and Prevention (CDC). Chronic Kidney Disease Surveillance System-United States. Available online: www.cdc.gov/ckd (accessed on 16 September 2016).

21. Centers for Disease Control and Prevention (CDC). Summary Health Statistics: National Health Interview Survey; U.S. Department of Human and Heath Services; Centers for Disease Control and Prevention: Atlanta, GA, USA, 2014.

22. Jha, V.; Garcia-Garcia, G.; Iseki, K.; Li, Z.; Naicker, S.; Plattner, B.; Saran, R.; Wang, A.Y.; Yang, C.W. Chronic kidney disease: Global dimension and perspectives. Lancet 2013, 382, 260-272. [CrossRef]

23. Centers of Disease Control and Prevention (CDC). National Chronic Kidney Disease Fact Sheet: General Information and National Estimates on Chronic Kidney Disease in the United States; US Department of Heath and Human Services: Atlanta, GA, USA, 2014.

24. Fine, L.G.; Norman, J.T.; Kujubu, D.A.; Knecht, A. Renal Hypertrophy. In The Kidney: Physiology and Pathophysiology, 2nd ed.; Seldin, D.W., Giebisch, G., Eds.; Raven Press: New York, NY, USA, 1992; pp. 3113-3133.

25. Salehmoghaddam, S.; Bradley, T.; Mikhail, N.; Badie-Dezfooly, B.; Nord, E.P.; Trizna, W.; Kheyfets, R.; Fine, L.G. Hypertrophy of basolateral Na-K pump activity in the proximal tubule of the remnant kidney. Lab. Investig. 1985, 53, 443-452. [PubMed]

26. Toback, F.G.; Smith, P.D.; Lowenstein, L.M. Phospholipid metabolism in the initiation of renal compensatory growth after acute reduction of renal mass. J. Clin. Investig. 1974, 54, 91-97. [CrossRef] [PubMed]

27. Wolf, G. Cellular mechanisms of tubule hypertrophy and hyperplasia in renal injury. Miner Electrolyte Metab. 1995, 21, 303-316. [PubMed]

28. Bricker, N.S.; Fine, L.G. The Renal Response to Progressive Nephron Loss. In The Kidney, 2nd ed.; Brenner, B.M., Rector, F.C., Eds.; Saunders: Philadelphia, PA, USA, 1981; Volume 1, pp. 1056-1096.

29. Klahr, S. Progression of chronic renal disease. Nutrition 1990, 6, 207-212. [PubMed]

30. Fine, L.G.; Norman, J. Cellular events in renal hypertrophy. Annu. Rev. Physiol. 1989, 51, 19-32. [CrossRef] [PubMed]

31. Lopez-Novoa, J.M. The Mechanisms of Age-Associated Glomerular Sclerosis. In The Aging Kidney in Health and Disease; Macias Nunez, J.F., Cameron, J.S., Oreopoulos, D.G., Eds.; Springer: New York, NY, USA, 2008; pp. 113-126.

32. Roels, H.A.; Lauwerys, R.R.; Bernard, A.M.; Buchet, J.P.; Vos, A.; Oversteyns, M. Assessment of the filtration reserve capacity of the kidney in workers exposed to cadmium. Br. J. Ind. Med. 1991, 48, 365-374. [CrossRef] [PubMed]

33. Uriu, K.; Kaizu, K.; Qie, Y.L.; Ito, A.; Takagi, I.; Suzuka, K.; Inada, Y.; Hashimoto, O.; Eto, S. Long-term oral intake of low-dose cadmium exacerbates age-related impairment of renal functional reserve in rats. Toxicol. Appl. Pharmacol. 2000, 169, 151-158. [CrossRef] [PubMed]

34. Zalups, R.K. Reductions in renal mass and the nephropathy induced by mercury. Toxicol. Appl. Pharmacol. 1997, 143, 366-379. [CrossRef] [PubMed] 
35. Agency for Toxic Substances and Disease Registry (ATSDR). Public Health Statement: Arsenic; Centers for Disease Control and Prevention: Atlanta, GA, USA, 2007.

36. Sattar, A.; Xie, S.; Hafeez, M.A.; Wang, X.; Hussain, H.I.; Iqbal, Z.; Pan, Y.; Iqbal, M.; Shabbir, M.A.; Yuan, Z. Metabolism and toxicity of arsenicals in mammals. Environ. Toxicol. Pharmacol. 2016, 48, 214-224. [CrossRef] [PubMed]

37. Thomas, D.J.; Styblo, M.; Lin, S. The cellular metabolism and systemic toxicity of arsenic. Toxicol. Appl. Pharmacol. 2001, 176, 127-144. [CrossRef] [PubMed]

38. Calatayud, M.; Barrios, J.A.; Velez, D.; Devesa, V. In vitro study of transporters involved in intestinal absorption of inorganic arsenic. Chem. Res. Toxicol. 2012, 25, 446-453. [CrossRef] [PubMed]

39. Tseng, W.P.; Chu, H.M.; How, S.W.; Fong, J.M.; Lin, C.S.; Yeh, S. Prevalence of skin cancer in an endemic area of chronic arsenicism in Taiwan. J. Natl. Cancer Inst. 1968, 40, 453-463. [PubMed]

40. Engel, R.R.; Hopenhayn-Rich, C.; Receveur, O.; Smith, A.H. Vascular effects of chronic arsenic exposure: A review. Epidemiol. Rev. 1994, 16, 184-209. [CrossRef] [PubMed]

41. Sung, T.C.; Huang, J.W.; Guo, H.R. Association between Arsenic Exposure and Diabetes: A Meta-Analysis. BioMed Res. Int. 2015, 2015, 368087. [CrossRef] [PubMed]

42. Sengupta, S.R.; Das, N.K.; Datta, P.K. Pathogenesis, clinical features and pathology of chronic arsenicosis. Indian J. Dermatol. Venereol. Leprol. 2008, 74, 559-570. [PubMed]

43. Lin, S.; Shi, Q.; Nix, F.B.; Styblo, M.; Beck, M.A.; Herbin-Davis, K.M.; Hall, L.L.; Simeonsson, J.B.; Thomas, D.J. A novel S-adenosyl-L-methionine: Arsenic(III) methyltransferase from rat liver cytosol. J. Biol. Chem. 2002, 277, 10795-10803. [CrossRef] [PubMed]

44. Healy, S.M.; Casarez, E.A.; Ayala-Fierro, F.; Aposhian, H. Enzymatic methylation of arsenic compounds. V. Arsenite methyltransferase activity in tissues of mice. Toxicol. Appl. Pharmacol. 1998, 148, 65-70. [CrossRef] [PubMed]

45. Thomas, D.J.; Li, J.; Waters, S.B.; Xing, W.; Adair, B.M.; Drobna, Z.; Devesa, V.; Styblo, M. Arsenic (+3 oxidation state) methyltransferase and the methylation of arsenicals. Exp. Biol. Med. 2007, 232, 3-13.

46. Petrick, J.S.; Ayala-Fierro, F.; Cullen, W.R.; Carter, D.E.; Vasken Aposhian, H. Monomethylarsonous acid (MMA(III)) is more toxic than arsenite in Chang human hepatocytes. Toxicol. Appl. Pharmacol. 2000, 163, 203-207. [CrossRef] [PubMed]

47. Styblo, M.; Del Razo, L.M.; Vega, L.; Germolec, D.R.; LeCluyse, E.L.; Hamilton, G.A.; Reed, W.; Wang, C.; Cullen, W.R.; Thomas, D.J. Comparative toxicity of trivalent and pentavalent inorganic and methylated arsenicals in rat and human cells. Arch. Toxicol. 2000, 74, 289-299. [CrossRef] [PubMed]

48. Mass, M.J.; Tennant, A.; Roop, B.C.; Cullen, W.R.; Styblo, M.; Thomas, D.J.; Kligerman, A.D. Methylated trivalent arsenic species are genotoxic. Chem. Res. Toxicol. 2001, 14, 355-361. [CrossRef] [PubMed]

49. Styblo, M.; Serves, S.V.; Cullen, W.R.; Thomas, D.J. Comparative inhibition of yeast glutathione reductase by arsenicals and arsenothiols. Chem. Res. Toxicol. 1997, 10, 27-33. [CrossRef] [PubMed]

50. Chouchane, S.; Snow, E.T. In vitro effect of arsenical compounds on glutathione-related enzymes. Chem. Res. Toxicol. 2001, 14, 517-522. [CrossRef] [PubMed]

51. Lin, S.; Del Razo, L.M.; Styblo, M.; Wang, C.; Cullen, W.R.; Thomas, D.J. Arsenicals inhibit thioredoxin reductase in cultured rat hepatocytes. Chem. Res. Toxicol. 2001, 14, 305-311. [CrossRef] [PubMed]

52. Lin, S.; Cullen, W.R.; Thomas, D.J. Methylarsenicals and arsinothiols are potent inhibitors of mouse liver thioredoxin reductase. Chem. Res. Toxicol. 1999, 12, 924-930. [CrossRef] [PubMed]

53. Petrick, J.S.; Jagadish, B.; Mash, E.A.; Aposhian, H.V. Monomethylarsonous acid (MMA(III)) and arsenite: $\mathrm{LD}(50)$ in hamsters and in vitro inhibition of pyruvate dehydrogenase. Chem. Res. Toxicol. 2001, 14, 651-656. [CrossRef] [PubMed]

54. Fowler, B.A.; Chou, S.J.; Jones, R.L.; Chen, C.J. Arsenic. In Handbook on the Toxicology of Metals, 3rd ed.; Nordberg, G.F., Fowler, B.A., Nordberg, M., Freiberg, L., Eds.; Elsevier: Amsterdam, The Netherlands, 2007; pp. 367-443.

55. Liu, Z.; Sanchez, M.A.; Jiang, X.; Boles, E.; Landfear, S.M.; Rosen, B.P. Mammalian glucose permease GLUT1 facilitates transport of arsenic trioxide and methylarsonous acid. Biochem. Biophys. Res. Commun. 2006, 351, 424-430. [CrossRef] [PubMed]

56. Sugawara-Yokoo, M.; Suzuki, T.; Matsuzaki, T.; Naruse, T.; Takata, K. Presence of fructose transporter GLUT5 in the S3 proximal tubules in the rat kidney. Kidney Int. 1999, 56, 1022-1028. [CrossRef] [PubMed] 
57. Dominguez, J.H.; Camp, K.; Maianu, L.; Garvey, W.T. Glucose transporters of rat proximal tubule: Differential expression and subcellular distribution. Am. J. Physiol. 1992, 262, F807-F812. [PubMed]

58. Lee, T.C.; Ho, I.C.; Lu, W.J.; Huang, J.D. Enhanced expression of multidrug resistance-associated protein 2 and reduced expression of aquaglyceroporin 3 in an arsenic-resistant human cell line. J. Biol. Chem. 2006, 281, 18401-18407. [CrossRef] [PubMed]

59. Bedford, J.J.; Leader, J.P.; Walker, R.J. Aquaporin expression in normal human kidney and in renal disease. J. Am. Soc. Nephrol. 2003, 14, 2581-2587. [CrossRef] [PubMed]

60. Lu, W.J.; Tamai, I.; Nezu, J.; Lai, M.L.; Huang, J.D. Organic anion transporting polypeptide-C mediates arsenic uptake in HEK-293 cells. J. Biomed. Sci. 2006, 13, 525-533. [CrossRef] [PubMed]

61. Aleksunes, L.M.; Augustine, L.M.; Scheffer, G.L.; Cherrington, N.J.; Manautou, J.E. Renal xenobiotic transporters are differentially expressed in mice following cisplatin treatment. Toxicology 2008, 250, 82-88. [CrossRef] [PubMed]

62. Roggenbeck, B.A.; Banerjee, M.; Leslie, E.M. Cellular arsenic transport pathways in mammals. J. Environ. Sci. 2016, 49, 38-58. [CrossRef] [PubMed]

63. Kala, S.V.; Kala, G.; Prater, C.I.; Sartorelli, A.C.; Lieberman, M.W. Formation and urinary excretion of arsenic triglutathione and methylarsenic diglutathione. Chem. Res. Toxicol. 2004, 17, 243-249. [CrossRef] [PubMed]

64. Roggenbeck, B.A.; Carew, M.W.; Charrois, G.J.; Douglas, D.N.; Kneteman, N.M.; Lu, X.; Le, X.C.; Leslie, E.M. Characterization of arsenic hepatobiliary transport using sandwich-cultured human hepatocytes. Toxicol. Sci. 2015, 145, 307-320. [CrossRef] [PubMed]

65. Yehiayan, L.; Stice, S.; Liu, G.; Matulis, S.; Boise, L.H.; Cai, Y. Dimethylarsinothioyl glutathione as a metabolite in human multiple myeloma cell lines upon exposure to Darinaparsin. Chem. Res. Toxicol. 2014, 27, 754-764. [CrossRef] [PubMed]

66. Thomas, D.J. Unraveling arsenic-Glutathione connections. Toxicol. Sci. 2009, 107, 309-311. [CrossRef] [PubMed]

67. Scott, N.; Hatlelid, K.M.; MacKenzie, N.E.; Carter, D.E. Reactions of arsenic(III) and arsenic(V) species with glutathione. Chem. Res. Toxicol. 1993, 6, 102-106. [CrossRef] [PubMed]

68. Delnomdedieu, M.; Basti, M.M.; Styblo, M.; Otvos, J.D.; Thomas, D.J. Complexation of arsenic species in rabbit erythrocytes. Chem. Res. Toxicol. 1994, 7, 621-627. [CrossRef] [PubMed]

69. Liu, J.; Chen, H.; Miller, D.S.; Saavedra, J.E.; Keefer, L.K.; Johnson, D.R.; Klaassen, C.D.; Waalkes, M.P. Overexpression of glutathione $S$-transferase II and multidrug resistance transport proteins is associated with acquired tolerance to inorganic arsenic. Mol. Pharmacol. 2001, 60, 302-309. [PubMed]

70. Vernhet, L.; Seite, M.P.; Allain, N.; Guillouzo, A.; Fardel, O. Arsenic induces expression of the multidrug resistance-associated protein 2 (MRP2) gene in primary rat and human hepatocytes. J. Pharmacol. Exp. Ther. 2001, 298, 234-239. [PubMed]

71. Drobna, Z.; Walton, F.S.; Paul, D.S.; Xing, W.; Thomas, D.J.; Styblo, M. Metabolism of arsenic in human liver: The role of membrane transporters. Arch. Toxicol. 2010, 84, 3-16. [CrossRef] [PubMed]

72. Gao, Y.; Pei, Q.L.; Li, G.X.; Han, G.; Tian, F.J.; Qin, X.J.; Zhang, R.; Hou, W.S.; Li, X.Y. Effects of MRP2-GSH cotransport system on hepatic arsenic metabolism in rats. Chin. J. Ind. Hyg. Occup. Dis. 2006, 24, 278-280.

73. Leslie, E.M.; Deeley, R.G.; Cole, S.P. Multidrug resistance proteins: Role of P-glycoprotein, MRP1, MRP2, and BCRP (ABCG2) in tissue defense. Toxicol. Appl. Pharmacol. 2005, 204, 216-237. [CrossRef] [PubMed]

74. Carew, M.W.; Leslie, E.M. Selenium-dependent and -independent transport of arsenic by the human multidrug resistance protein 2 (MRP2/ABCC2): Implications for the mutual detoxification of arsenic and selenium. Carcinogenesis 2010, 31, 1450-1455. [CrossRef] [PubMed]

75. Banerjee, M.; Carew, M.W.; Roggenbeck, B.A.; Whitlock, B.D.; Naranmandura, H.; Le, X.C.; Leslie, E.M. A novel pathway for arsenic elimination: Human multidrug resistance protein 4 (MRP4/ABCC4) mediates cellular export of dimethylarsinic acid (DMAV) and the diglutathione conjugate of monomethylarsonous acid (MMAIII). Mol. Pharmacol. 2014, 86, 168-179. [CrossRef] [PubMed]

76. Kimura, A.; Ishida, Y.; Hayashi, T.; Wada, T.; Yokoyama, H.; Sugaya, T.; Mukaida, N.; Kondo, T. Interferon-gamma plays protective roles in sodium arsenite-induced renal injury by up-regulating intrarenal multidrug resistance-associated protein 1 expression. Am. J. Pathol. 2006, 169, 1118-1128. [CrossRef] [PubMed] 
77. Chin, K.V.; Tanaka, S.; Darlington, G.; Pastan, I.; Gottesman, M.M. Heat shock and arsenite increase expression of the multidrug resistance (MDR1) gene in human renal carcinoma cells. J. Biol. Chem. 1990, 265, 221-226. [PubMed]

78. Liu, J.; Liu, Y.; Powell, D.A.; Waalkes, M.P.; Klaassen, C.D. Multidrug-resistance mdr1a/1b double knockout mice are more sensitive than wild type mice to acute arsenic toxicity, with higher arsenic accumulation in tissues. Toxicology 2002, 170, 55-62. [CrossRef]

79. Xie, Y.; Liu, J.; Liu, Y.; Klaassen, C.D.; Waalkes, M.P. Toxicokinetic and genomic analysis of chronic arsenic exposure in multidrug-resistance mdr1a/1b(-/-) double knockout mice. Mol. Cell. Biochem. 2004, 255, 11-18. [CrossRef] [PubMed]

80. George, B.; You, D.; Joy, M.S.; Aleksunes, L.M. Xenobiotic transporters and kidney injury. Adv. Drug Deliv. Rev. 2017. [CrossRef] [PubMed]

81. Yang, H.; Guo, D.; Obianom, O.N.; Su, T.; Polli, J.E.; Shu, Y. Multidrug and toxin extrusion proteins mediate cellular transport of cadmium. Toxicol. Appl. Pharmacol. 2017, 314, 55-62. [CrossRef] [PubMed]

82. Prasad, G.V.; Rossi, N.F. Arsenic intoxication associated with tubulointerstitial nephritis. Am. J. Kidney Dis. 1995, 26, 373-376. [CrossRef]

83. Robles-Osorio, M.L.; Sabath-Silva, E.; Sabath, E. Arsenic-mediated nephrotoxicity. Ren. Fail. 2015, 37, 542-547. [CrossRef] [PubMed]

84. Tsao, D.A.; Tseng, W.C.; Chang, H.R. RKIP expression of liver and kidney after arsenic exposure. Environ. Toxicol. 2017, 32, 1079-1082. [CrossRef] [PubMed]

85. Yeung, K.; Seitz, T.; Li, S.; Janosch, P.; McFerran, B.; Kaiser, C.; Fee, F.; Katsanakis, K.D.; Rose, D.W.; Mischak, H.; et al. Suppression of Raf-1 kinase activity and MAP kinase signalling by RKIP. Nature 1999, 401, 173-177. [PubMed]

86. Yeung, K.; Janosch, P.; McFerran, B.; Rose, D.W.; Mischak, H.; Sedivy, J.M.; Kolch, W. Mechanism of suppression of the Raf/MEK/extracellular signal-regulated kinase pathway by the raf kinase inhibitor protein. Mol. Cell. Biol. 2000, 20, 3079-3085. [CrossRef] [PubMed]

87. Odabaei, G.; Chatterjee, D.; Jazirehi, A.R.; Goodglick, L.; Yeung, K.; Bonavida, B. Raf-1 kinase inhibitor protein: Structure, function, regulation of cell signaling, and pivotal role in apoptosis. Adv. Cancer Res. 2004, 91, 169-200. [PubMed]

88. Singh, R.D.; Tiwari, R.; Khan, H.; Kumar, A.; Srivastava, V. Arsenic exposure causes epigenetic dysregulation of IL-8 expression leading to proneoplastic changes in kidney cells. Toxicol. Lett. 2015, 237, 1-10. [CrossRef] [PubMed]

89. Verdugo, M.; Ogra, Y.; Quiroz, W. Mechanisms underlying the toxic effects of antimony species in human embryonic kidney cells (HEK-293) and their comparison with arsenic species. J. Toxicol. Sci. 2016, 41, 783-792. [CrossRef] [PubMed]

90. Sinha, M.; Manna, P.; Sil, P.C. Arjunolic acid attenuates arsenic-induced nephrotoxicity. Pathophysiology 2008, 15, 147-156. [CrossRef] [PubMed]

91. Roy, A.; Manna, P.; Sil, P.C. Prophylactic role of taurine on arsenic mediated oxidative renal dysfunction via MAPKs / NF-kappaB and mitochondria dependent pathways. Free Radic. Res. 2009, 43, 995-1007. [CrossRef] [PubMed]

92. Gong, X.; Ivanov, V.N.; Davidson, M.M.; Hei, T.K. Tetramethylpyrazine (TMP) protects against sodium arsenite-induced nephrotoxicity by suppressing ROS production, mitochondrial dysfunction, pro-inflammatory signaling pathways and programed cell death. Arch. Toxicol. 2015, 89, 1057-1070. [CrossRef] [PubMed]

93. Orihuela, R.; Kojima, C.; Tokar, E.J.; Person, R.J.; Xu, Y.; Qu, W.; Waalkes, M.P. Oxidative DNA damage after acute exposure to arsenite and monomethylarsonous acid in biomethylation-deficient human cells. Toxicol. Mech. Methods 2013, 23, 389-395. [CrossRef] [PubMed]

94. Sasaki, A.; Oshima, Y.; Fujimura, A. An approach to elucidate potential mechanism of renal toxicity of arsenic trioxide. Exp. Hematol. 2007, 35, 252-262. [CrossRef] [PubMed]

95. Peraza, M.A.; Carter, D.E.; Gandolfi, A.J. Toxicity and metabolism of subcytotoxic inorganic arsenic in human renal proximal tubule epithelial cells (HK-2). Cell Biol. Exp. Toxicol. 2003, 19, 253-264. [CrossRef]

96. Lee, C.H.; Yu, H.S. Role of mitochondria, ROS, and DNA damage in arsenic induced carcinogenesis. Front. Biosci. 2016, 8, 312-320. 
97. Ganger, R.; Garla, R.; Mohanty, B.P.; Bansal, M.P.; Garg, M.L. Protective Effects of Zinc Against Acute Arsenic Toxicity by Regulating Antioxidant Defense System and Cumulative Metallothionein Expression. Biol. Trace Elem. Res. 2016, 169, 218-229. [CrossRef] [PubMed]

98. Cui, X.; Okayasu, R. Arsenic accumulation, elimination, and interaction with copper, zinc and manganese in liver and kidney of rats. Food Chem. Toxicol. 2008, 46, 3646-3650. [CrossRef] [PubMed]

99. Kreppel, H.; Bauman, J.W.; Liu, J.; McKim, J.M., Jr.; Klaassen, C.D. Induction of metallothionein by arsenicals in mice. Fundam. Appl. Toxicol. 1993, 20, 184-189. [CrossRef] [PubMed]

100. Garla, R.; Mohanty, B.P.; Ganger, R.; Sudarshan, M.; Bansal, M.P.; Garg, M.L. Metal stoichiometry of isolated and arsenic substituted metallothionein: PIXE and ESI-MS study. Biometals 2013, 26, 887-896. [CrossRef] [PubMed]

101. Garla, R.; Kaur, N.; Bansal, M.P.; Garg, M.L.; Mohanty, B.P. Quantum mechanical treatment of As ${ }^{3+}$-thiol model compounds: Implication for the core structure of As(III)-metallothionein. J. Mol. Model. 2017, 23, 78. [CrossRef] [PubMed]

102. Qu, W.; Waalkes, M.P. Metallothionein blocks oxidative DNA damage induced by acute inorganic arsenic exposure. Toxicol. Appl. Pharmacol. 2015, 282, 267-274. [CrossRef] [PubMed]

103. Garla, R.; Ganger, R.; Mohanty, B.P.; Verma, S.; Bansal, M.P.; Garg, M.L. Metallothionein does not sequester arsenic(III) ions in condition of acute arsenic toxicity. Toxicology 2016, 366-367, 68-73. [CrossRef] [PubMed]

104. Weidemann, D.; Kuo, C.C.; Navas-Acien, A.; Abraham, A.G.; Weaver, V.; Fadrowski, J. Association of arsenic with kidney function in adolescents and young adults: Results from the National Health and Nutrition Examination Survey 2009-2012. Environ. Res. 2015, 140, 317-324. [CrossRef] [PubMed]

105. Hsueh, Y.M.; Chung, C.J.; Shiue, H.S.; Chen, J.B.; Chiang, S.S.; Yang, M.H.; Tai, C.W.; Su, C.T. Urinary arsenic species and CKD in a Taiwanese population: A case-control study. Am. J. Kidney Dis. 2009, 54, 859-870. [CrossRef] [PubMed]

106. Vaziri, N.D.; Upham, T.; Barton, C.H. Hemodialysis clearance of arsenic. Clin. Toxicol. 1980, 17, 451-456. [CrossRef] [PubMed]

107. Zheng, L.Y.; Umans, J.G.; Yeh, F.; Francesconi, K.A.; Goessler, W.; Silbergeld, E.K.; Bandeen-Roche, K.; Guallar, E.; Howard, B.V.; Weaver, V.M.; et al. The association of urine arsenic with prevalent and incident chronic kidney disease: Evidence from the Strong Heart Study. Epidemiology 2015, 26, 601-612. [CrossRef] [PubMed]

108. Faroon, O.; Ashizawa, A.; Wright, S.; Tucker, P.; Jenkins, K.; Ingerman, L.; Rudisill, C. Toxicological Profile for Cadmium. In U.S. Department of Health and Human Services, Public Health Service; Centers for Disease Control and Prevention; Agency for Toxic Substances and Disease Registry (ATSDR): Atlanta, GA, USA, 2008.

109. World Health Organization (WHO). Cadmium -Environmental Health Criteria 134; World Health Organization (WHO): Geneva, Switzerland, 1992.

110. Friberg, L.; Piscator, M.; Nordberg, G.; Kjellstrom, T. Cadmium in the Environmnent, 2nd ed.; CRC Press: Cleveland, OH, USA, 1974.

111. Elinder, C.G.; Kjellstrom, T.; Lind, B.; Linnman, L.; Piscator, M.; Sundstedt, K. Cadmium exposure from smoking cigarettes: Variations with time and country where purchased. Environ. Res. 1983, 32, $220-227$. [CrossRef]

112. Elinder, C.G.; Lind, B.; Kjellstrom, T.; Linnman, L.; Friberg, L. Cadmium in kidney cortex, liver, and pancreas from Swedish autopsies. Estimation of biological half time in kidney cortex, considering calorie intake and smoking habits. Arch. Environ. Health 1976, 31, 292-302. [CrossRef] [PubMed]

113. Jarup, L.; Berglund, M.; Elinder, C.G.; Nordberg, G.; Vahter, M. Health effects of cadmium exposure-A review of the literature and a risk estimate. Scand. J. Work Environ. Health 1998, 24 (Suppl. S1), 1-51. [PubMed]

114. Olsson, I.M.; Bensryd, I.; Lundh, T.; Ottosson, H.; Skerfving, S.; Oskarsson, A. Cadmium in blood and urine-Impact of sex, age, dietary intake, iron status, and former smoking-Association of renal effects. Environ. Health Perspect. 2002, 110, 1185-1190. [CrossRef] [PubMed]

115. Centers for Disease Control (CDC); Community Futures Development Corporation (CFDC). Fourth National Report on Human Exposure to Environmental Chemicals; Centers for Disease Control (CDC): Atlanta, GA, USA, 2009; pp. 218-226.

116. Rabenstein, D.L.; Isab, A.A.; Kadima, W.; Mohanakrishnan, P. A proton nuclear magnetic resonance study of the interaction of cadmium with human erythrocytes. Biochim. Biophys. Acta 1983, 762, 531-541. [CrossRef] 
117. Rabenstein, D.L. Metal complexes of glutathione and their biological significance. In Glutathione: Chemical, Biochemical and Medical Aspects, Coenzymes and Cofactors; Dolphin, D., Auromovibic, O., Poulson, R., Eds.; Wiley: New York, NY, USA, 1989; Volume 3, pp. 147-186.

118. Wang, Y.; Zalups, R.K.; Barfuss, D.W. Potential mechanisms involved in the absorptive transport of cadmium in isolated perfused rabbit renal proximal tubules. Toxicol. Lett. 2010, 193, 61-68. [CrossRef] [PubMed]

119. Zalups, R.K.; Ahmad, S. Molecular handling of cadmium in transporting epithelia. Toxicol. Appl. Pharmacol. 2003, 186, 163-188. [CrossRef]

120. Soodvilai, S.; Nantavishit, J.; Muanprasat, C.; Chatsudthipong, V. Renal organic cation transporters mediated cadmium-induced nephrotoxicity. Toxicol. Lett. 2011, 204, 38-42. [CrossRef] [PubMed]

121. Thevenod, F.; Ciarimboli, G.; Leistner, M.; Wolff, N.A.; Lee, W.K.; Schatz, I.; Keller, T.; Al-Monajjed, R.; Gorboulev, V.; Koepsell, H. Substrate- and cell contact-dependent inhibitor affinity of human organic cation transporter 2: Studies with two classical organic cation substrates and the novel substrate $\mathrm{Cd}^{2+}$. Mol. Pharm. 2013, 10, 3045-3056. [CrossRef] [PubMed]

122. Sweet, D.H.; Miller, D.S.; Pritchard, J.B. Basolateral localization of organic cation transporter 2 in intact renal proximal tubules. Am. J. Physiol. Ren. Physiol. 2000, 279, F826-F834.

123. Karbach, U.; Kricke, J.; Meyer-Wentrup, F.; Gorboulev, V.; Volk, C.; Loffing-Cueni, D.; Kaissling, B.; Bachmann, S.; Koepsell, H. Localization of organic cation transporters OCT1 and OCT2 in rat kidney. Am. J. Physiol. Ren. Physiol. 2000, 279, F679-F687.

124. Felley-Bosco, E.; Diezi, J. Fate of cadmium in rat renal tubules: A micropuncture study. Toxicol. Appl. Pharmacol. 1989, 98, 243-251. [CrossRef]

125. Barbier, O.; Jacquillet, G.; Tauc, M.; Poujeol, P.; Cougnon, M. Acute study of interaction among cadmium, calcium, and zinc transport along the rat nephron in vivo. Am. J. Physiol. Ren. Physiol. 2004, 287, F1067-F1075. [CrossRef] [PubMed]

126. Dudley, R.E.; Gammal, L.M.; Klaassen, C.D. Cadmium-induced hepatic and renal injury in chronically exposed rats: Likely role of hepatic cadmium-metallothionein in nephrotoxicity. Toxicol. Appl. Pharmacol. 1985, 77, 414-426. [CrossRef]

127. Erfurt, C.; Roussa, E.; Thevenod, F. Apoptosis by $\mathrm{Cd}^{2+}$ or CdMT in proximal tubule cells: Different uptake routes and permissive role of endo/lysosomal CdMT uptake. Am. J. Physiol. Cell Physiol. 2003, 285, C1367-C1376. [CrossRef] [PubMed]

128. Murakami, M.; Sano, K.; Webb, M. The effect of L-cysteine on the portion-selective uptake of cadmium in the renal proximal tubule. Arch. Toxicol. 1987, 60, 365-369. [CrossRef] [PubMed]

129. Dorian, C.; Gattone, V.H., 2nd; Klaassen, C.D. Accumulation and degradation of the protein moiety of cadmium-metallothionein (CdMT) in the mouse kidney. Toxicol. Appl. Pharmacol. 1992, 117, 242-248. [CrossRef]

130. Dorian, C.; Gattone, V.H., 2nd; Klaasen, C.D. Renal cadmium deposition and injury as a result of accumulation of cadmium-metallothionein (CdMT) by the proximal convoluted tubules-A light microscopic autoradiography study with 109CdMT. Toxicol. Appl. Pharmacol. 1992, 114, 173-181. [CrossRef]

131. Foulkes, E.C. Renal tubular transport of cadmium-metallothionein. Toxicol. Appl. Pharmacol. 1978, 45, 505-512. [CrossRef]

132. Nordberg, M.; Jin, T.; Nordberg, G.F. Cadmium, metallothionein and renal tubular toxicity. IARC Sci. Publ. 1992, 118, 293-297.

133. Webb, M. Role of metallothionein in cadmium metabolism. In Cadmium; Foulkes, E.C., Ed.; Springer: Berlin, Germany; New York, NY, USA, 1986.

134. Thevenod, F. Catch me if you can! Novel aspects of cadmium transport in mammalian cells. Biometals 2010, 23, 857-875. [CrossRef] [PubMed]

135. Thevenod, F. Nephrotoxicity and the proximal tubule. Insights from cadmium. Nephron Physiol. 2003, 93, 87-93. [CrossRef]

136. Nordberg, G.F.; Goyer, R.; Nordberg, M. Comparative toxicity of cadmium-metallothionein and cadmium chloride on mouse kidney. Arch. Pathol. 1975, 99, 192-197. [PubMed]

137. Cherian, M.G.; Nordberg, M. Cellular adaptation in metal toxicology and metallothionein. Toxicology 1983, 28, 1-15. [PubMed]

138. Felley-Bosco, E.; Diezi, J. Fate of cadmium in rat renal tubules: A microinjection study. Toxicol. Appl. Pharmacol. 1987, 91, 204-211. [PubMed] 
139. Murakami, M.; Cain, K.; Webb, M. Cadmium-metallothionein-induced nephropathy: A morphological and autoradiographic study of cadmium distribution, the development of tubular damage and subsequent cell regeneration. J. Appl. Toxicol. 1983, 3, 237-244. [PubMed]

140. Zalups, R.K.; Gelein, R.M.; Cherian, M.G. Shifts in the dose-effect relationship for the nephropathy induced by cadmium-metallothionein in rats after a reduction in renal mass. J. Pharmacol. Exp. Ther. 1992, 262, 1256-1266. [PubMed]

141. Abouhamed, M.; Wolff, N.A.; Lee, W.K.; Smith, C.P.; Thevenod, F. Knockdown of endosomal/lysosomal divalent metal transporter 1 by RNA interference prevents cadmium-metallothionein-1 cytotoxicity in renal proximal tubule cells. Am. J. Physiol. Ren. Physiol. 2007, 293, F705-F712.

142. Ferguson, C.J.; Wareing, M.; Ward, D.T.; Green, R.; Smith, C.P.; Riccardi, D. Cellular localization of divalent metal transporter DMT-1 in rat kidney. Am. J. Physiol. Ren. Physiol. 2001, 280, F803-F814.

143. Scheuhammer, A.M.; Cherian, M.G. Quantification of metallothioneins by a silver-saturation method. Toxicol. Appl. Pharmacol. 1986, 82, 417-425. [PubMed]

144. Wang, B.; Schneider, S.N.; Dragin, N.; Girijashanker, K.; Dalton, T.P.; He, L.; Miller, M.L.; Stringer, K.F.; Soleimani, M.; Richardson, D.D.; et al. Enhanced cadmium-induced testicular necrosis and renal proximal tubule damage caused by gene-dose increase in a Slc39a8-transgenic mouse line. Am. J. Physiol. Cell Physiol. 2007, 292, C1523-C1535. [PubMed]

145. Girijashanker, K.; He, L.; Soleimani, M.; Reed, J.M.; Li, H.; Liu, Z.; Wang, B.; Dalton, T.P.; Nebert, D.W. Slc39a14 gene encodes ZIP14, a metal/bicarbonate symporter: Similarities to the ZIP8 transporter. Mol. Pharmacol. 2008, 73, 1413-1423. [PubMed]

146. Fujishiro, H.; Okugaki, S.; Kubota, K.; Fujiyama, T.; Miyataka, H.; Himeno, S. The role of ZIP8 down-regulation in cadmium-resistant metallothionein-null cells. J. Appl. Toxicol. 2009, 29, 367-373. [CrossRef] [PubMed]

147. Fujishiro, H.; Yano, Y.; Takada, Y.; Tanihara, M.; Himeno, S. Roles of ZIP8, ZIP14, and DMT1 in transport of cadmium and manganese in mouse kidney proximal tubule cells. Metallomics 2012, 4, 700-708. [CrossRef] [PubMed]

148. He, L.; Wang, B.; Hay, E.B.; Nebert, D.W. Discovery of ZIP transporters that participate in cadmium damage to testis and kidney. Toxicol. Appl. Pharmacol. 2009, 238, 250-257. [CrossRef] [PubMed]

149. Zhang, R.; Witkowska, K.; Afonso Guerra-Assuncao, J.; Ren, M.; Ng, F.L.; Mauro, C.; Tucker, A.T.; Caulfield, M.J.; Ye, S. A blood pressure-associated variant of the SLC39A8 gene influences cellular cadmium accumulation and toxicity. Hum. Mol. Genet. 2016, 25, 4117-4126. [CrossRef] [PubMed]

150. Otsuka, M.; Matsumoto, T.; Morimoto, R.; Arioka, S.; Omote, H.; Moriyama, Y. A human transporter protein that mediates the final excretion step for toxic organic cations. Proc. Natl. Acad. Sci. USA 2005, 102, 17923-17928. [CrossRef] [PubMed]

151. Masuda, S.; Terada, T.; Yonezawa, A.; Tanihara, Y.; Kishimoto, K.; Katsura, T.; Ogawa, O.; Inui, K. Identification and functional characterization of a new human kidney-specific $\mathrm{H}^{+}$/organic cation antiporter, kidney-specific multidrug and toxin extrusion 2. J. Am. Soc. Nephrol. 2006, 17, 2127-2135. [CrossRef] [PubMed]

152. Carriere, P.; Mantha, M.; Champagne-Paradis, S.; Jumarie, C. Characterization of basolateral-to-apical transepithelial transport of cadmium in intestinal TC7 cell monolayers. Biometals 2011, 24, 857-874. [CrossRef] [PubMed]

153. Prozialeck, W.C.; Edwards, J.R. Early biomarkers of cadmium exposure and nephrotoxicity. Biometals 2010, 23, 793-809. [CrossRef] [PubMed]

154. Elinder, C.G.; Gerhardsson, L.; Oberdorster, G. Biological monitoring of toxic metals: Overview. In Biological Monitoring of Toxic Metals; Clarkson, T.W., Friberg, L., Nordberg, G.F., Sager, P.R., Eds.; Plenum Press: London, UK, 1988; pp. 1-71.

155. Nordberg, G.F.; Nogawa, K.; Nordberg, M.; Friedmann, J.M. Cadmium. In Handbook on the Toxicology of Metals; Nordberg, G.F., Fowler, B.A., Nordberg, M., Friberg, L., Eds.; Elsevier: Amsterdam, The Netherlands, 2007; pp. 445-486.

156. Nordberg, G.F.; Nordberg, M. Biological monitoring of cadmium. In Biological Monitoring of Toxic Metals; Clarkson, T.W., Friberg, L., Nordberg, G.F., Sager, P.R., Eds.; Plenum Press: New York, NY, USA, 2001; pp. 151-168. 
157. Johri, N.; Jacquillet, G.; Unwin, R. Heavy metal poisoning: The effects of cadmium on the kidney. Biometals 2010, 23, 783-792. [CrossRef] [PubMed]

158. Prozialeck, W.C.; VanDreel, A.; Ackerman, C.D.; Stock, I.; Papaeliou, A.; Yasmine, C.; Wilson, K.; Lamar, P.C.; Sears, V.L.; Gasiorowski, J.Z.; et al. Evaluation of cystatin C as an early biomarker of cadmium nephrotoxicity in the rat. Biometals 2016, 29, 131-146. [CrossRef] [PubMed]

159. Akesson, A.; Lundh, T.; Vahter, M.; Bjellerup, P.; Lidfeldt, J.; Nerbrand, C.; Samsioe, G.; Stromberg, U.; Skerfving, S. Tubular and glomerular kidney effects in Swedish women with low environmental cadmium exposure. Environ. Health Perspect. 2005, 113, 1627-1631. [CrossRef] [PubMed]

160. Tsuchiya, K.; Iwao, S.; Sugita, M.; Sakurai, H. Increased urinary beta 2-microglobulin in cadmium exposure: Dose-effect relationship and biological significance of beta 2-microglobulin. Environ. Health Perspect. 1979, 28, 147-153. [PubMed]

161. Jin, T.; Nordberg, G.; Wu, X.; Ye, T.; Kong, Q.; Wang, Z.; Zhuang, F.; Cai, S. Urinary N-acetyl-beta-D-glucosaminidase isoenzymes as biomarker of renal dysfunction caused by cadmium in a general population. Environ. Res. 1999, 81, 167-173. [CrossRef] [PubMed]

162. Prozialeck, W.C.; Vaidya, V.S.; Liu, J.; Waalkes, M.P.; Edwards, J.R.; Lamar, P.C.; Bernard, A.M.; Dumont, X.; Bonventre, J.V. Kidney injury molecule-1 is an early biomarker of cadmium nephrotoxicity. Kidney Int. 2007, 72, 985-993. [CrossRef] [PubMed]

163. Jarup, L.; Alfven, T. Low level cadmium exposure, renal and bone effects-The OSCAR study. Biometals 2004, 17, 505-509. [CrossRef] [PubMed]

164. Jarup, L.; Hellstrom, L.; Alfven, T.; Carlsson, M.D.; Grubb, A.; Persson, B.; Pettersson, C.; Spang, G.; Schutz, A.; Elinder, C.G. Low level exposure to cadmium and early kidney damage: The OSCAR study. Occup. Environ. Med. 2000, 57, 668-672. [CrossRef] [PubMed]

165. Noonan, C.W.; Sarasua, S.M.; Campagna, D.; Kathman, S.J.; Lybarger, J.A.; Mueller, P.W. Effects of exposure to low levels of environmental cadmium on renal biomarkers. Environ. Health Perspect. 2002, 110, 151-155. [CrossRef] [PubMed]

166. Mortensen, M.E.; Wong, L.Y.; Osterloh, J.D. Smoking status and urine cadmium above levels associated with subclinical renal effects in U.S. adults without chronic kidney disease. Int. J. Hyg. Environ. Health 2011, 214, 305-310. [CrossRef] [PubMed]

167. Huang, M.; Choi, S.J.; Kim, D.W.; Kim, N.Y.; Park, C.H.; Yu, S.D.; Kim, D.S.; Park, K.S.; Song, J.S.; Kim, H.; et al. Risk assessment of low-level cadmium and arsenic on the kidney. J. Toxicol. Environ. Health A 2009, 72, 1493-1498. [CrossRef] [PubMed]

168. Sabolic, I.; Ljubojevic, M.; Herak-Kramberger, C.M.; Brown, D. Cd-MT causes endocytosis of brush-border transporters in rat renal proximal tubules. Am. J. Physiol. Ren. Physiol. 2002, 283, F1389-F1402. [CrossRef]

169. Herak-Kramberger, C.M.; Brown, D.; Sabolic, I. Cadmium inhibits vacuolar H(+)-ATPase and endocytosis in rat kidney cortex. Kidney Int. 1998, 53, 1713-1726. [CrossRef] [PubMed]

170. Wolff, N.A.; Abouhamed, M.; Verroust, P.J.; Thevenod, F. Megalin-dependent internalization of cadmium-metallothionein and cytotoxicity in cultured renal proximal tubule cells. J. Pharmacol. Exp. Ther. 2006, 318, 782-791. [CrossRef] [PubMed]

171. Santoyo-Sanchez, M.P.; Pedraza-Chaverri, J.; Molina-Jijon, E.; Arreola-Mendoza, L.; Rodriguez-Munoz, R.; Barbier, O.C. Impaired endocytosis in proximal tubule from subchronic exposure to cadmium involves angiotensin II type 1 and cubilin receptors. BMC Nephrol. 2013, 14, 211. [CrossRef] [PubMed]

172. Yang, L.Y.; Wu, K.H.; Chiu, W.T.; Wang, S.H.; Shih, C.M. The cadmium-induced death of mesangial cells results in nephrotoxicity. Autophagy 2009, 5, 571-572. [CrossRef] [PubMed]

173. Liu, Y.; Templeton, D.M. Cadmium activates CaMK-II and initiates CaMK-II-dependent apoptosis in mesangial cells. FEBS Lett. 2007, 581, 1481-1486. [CrossRef] [PubMed]

174. Jarup, L.; Persson, B.; Elinder, C.G. Decreased glomerular filtration rate in solderers exposed to cadmium. Occup. Environ. Med. 1995, 52, 818-822. [CrossRef] [PubMed]

175. Brzoska, M.M.; Kaminski, M.; Dziki, M.; Moniuszko-Jakoniuk, J. Changes in the structure and function of the kidney of rats chronically exposed to cadmium. II. Histoenzymatic studies. Arch. Toxicol. 2004, 78, $226-231$. [PubMed]

176. Jarup, L.; Elinder, C.G. Incidence of renal stones among cadmium exposed battery workers. Br. J. Ind. Med. 1993, 50, 598-602. [CrossRef] [PubMed] 
177. Aoshima, K.; Kasuya, M. Preliminary study on serum levels of 1,25-dihydroxyvitamin D and 25-hydroxyvitamin D in cadmium-induced renal tubular dysfunction. Toxicol. Lett. 1991, 57, 91-99. [PubMed]

178. Tsuritani, I.; Honda, R.; Ishizaki, M.; Yamada, Y.; Kido, T.; Nogawa, K. Impairment of vitamin D metabolism due to environmental cadmium exposure, and possible relevance to sex-related differences in vulnerability to the bone damage. J. Toxicol. Environ. Health 1992, 37, 519-533. [CrossRef] [PubMed]

179. Galazyn-Sidorczuk, M.; Brzoska, M.M.; Jurczuk, M.; Moniuszko-Jakoniuk, J. Oxidative damage to proteins and DNA in rats exposed to cadmium and/or ethanol. Chem. Biol. Interact. 2009, 180, 31-38. [CrossRef] [PubMed]

180. Matovic, V.; Buha, A.; Ethukic-Cosic, D.; Bulat, Z. Insight into the oxidative stress induced by lead and/or cadmium in blood, liver and kidneys. Food Chem. Toxicol. 2015, 78, 130-140. [CrossRef] [PubMed]

181. So, K.Y.; Oh, S.H. Cadmium-induced heme-oxygenase-1 expression plays dual roles in autophagy and apoptosis and is regulated by both PKC-delta and PKB/Akt activation in NRK52E kidney cells. Toxicology 2016, 370, 49-59. [CrossRef] [PubMed]

182. Chen, Z.; Gu, D.; Zhou, M.; Shi, H.; Yan, S.; Cai, Y. Regulatory role of miR-125a/b in the suppression by selenium of cadmium-induced apoptosis via the mitochondrial pathway in LLC-PK1 cells. Chem. Biol. Interact. 2016, 243, 35-44. [CrossRef] [PubMed]

183. Babaknejad, N.; Moshtaghie, A.A.; Nayeri, H.; Hani, M.; Bahrami, S. Protective Role of Zinc and Magnesium against Cadmium Nephrotoxicity in Male Wistar Rats. Biol. Trace Elem. Res. 2016, 174, 112-120. [CrossRef] [PubMed]

184. Lin, Y.S.; Ho, W.C.; Caffrey, J.L.; Sonawane, B. Low serum zinc is associated with elevated risk of cadmium nephrotoxicity. Environ. Res. 2014, 134, 33-38. [CrossRef] [PubMed]

185. Jihen el, H.; Imed, M.; Fatima, H.; Abdelhamid, K. Protective effects of selenium (Se) and zinc (Zn) on cadmium (Cd) toxicity in the liver and kidney of the rat: Histology and Cd accumulation. Food Chem. Toxicol. 2008, 46, 3522-3527. [CrossRef] [PubMed]

186. Liu, J.; Liu, Y.; Habeebu, S.S.; Klaassen, C.D. Metallothionein-null mice are highly susceptible to the hematotoxic and immunotoxic effects of chronic $\mathrm{CdCl} 2$ exposure. Toxicol. Appl. Pharmacol. 1999, 159, 98-108. [CrossRef] [PubMed]

187. Brzoska, M.M.; Roszczenko, A.; Galazyn-Sidorczuk, M.; Majewska, K. Zinc supplementation can protect from enhanced risk of femoral neck fracture in male rats chronically exposed to cadmium. Exp. Toxicol. Pathol. 2011, 63, 491-498. [CrossRef] [PubMed]

188. Jihen el, H.; Fatima, H.; Nouha, A.; Baati, T.; Imed, M.; Abdelhamid, K. Cadmium retention increase: A probable key mechanism of the protective effect of zinc on cadmium-induced toxicity in the kidney. Toxicol. Lett. 2010, 196, 104-109. [CrossRef] [PubMed]

189. Jacquillet, G.; Barbier, O.; Cougnon, M.; Tauc, M.; Namorado, M.C.; Martin, D.; Reyes, J.L.; Poujeol, P. Zinc protects renal function during cadmium intoxication in the rat. Am. J. Physiol. Ren. Physiol. 2006, 290, F127-F137. [CrossRef] [PubMed]

190. Zhang, D.; Liu, J.; Gao, J.; Shahzad, M.; Han, Z.; Wang, Z.; Li, J.; Sjolinder, H. Zinc supplementation protects against cadmium accumulation and cytotoxicity in Madin-Darby bovine kidney cells. PLoS ONE 2014, 9, e103427. [CrossRef] [PubMed]

191. Matovic, V.; Buha, A.; Bulat, Z.; Dukic-Cosic, D. Cadmium toxicity revisited: Focus on oxidative stress induction and interactions with zinc and magnesium. Arhiv Hig. Rada Toksikol. 2011, 62, 65-76. [CrossRef] [PubMed]

192. Matovic, V.; Plamenac Bulat, Z.; Djukic-Cosic, D.; Soldatovic, D. Antagonism between cadmium and magnesium: A possible role of magnesium in therapy of cadmium intoxication. Magnes. Res. 2010, 23, 19-26. [PubMed]

193. Quamme, G.A. Free cadmium activity in renal epithelial cells is enhanced by $\mathrm{Mg}^{2+}$ depletion. Kidney Int. 1992, 41, 1237-1244. [CrossRef] [PubMed]

194. Djukic-Cosic, D.; Ninkovic, M.; Malicevic, Z.; Matovic, V.; Soldatovic, D. Effect of magnesium pretreatment on reduced glutathione levels in tissues of mice exposed to acute and subacute cadmium intoxication: A time course study. Magnes. Res. 2007, 20, 177-186. [PubMed]

195. Huang, M.; Choi, S.J.; Kim, D.W.; Kim, N.Y.; Bae, H.S.; Yu, S.D.; Kim, D.S.; Kim, H.; Choi, B.S.; Yu, I.J.; et al. Evaluation of factors associated with cadmium exposure and kidney function in the general population. Environ. Toxicol. 2011, 28, 563-570. [CrossRef] [PubMed] 
196. Ferraro, P.M.; Costanzi, S.; Naticchia, A.; Sturniolo, A.; Gambaro, G. Low level exposure to cadmium increases the risk of chronic kidney disease: Analysis of the NHANES 1999-2006. BMC Public Health 2010, 10, 304. [CrossRef] [PubMed]

197. Navas-Acien, A.; Tellez-Plaza, M.; Guallar, E.; Muntner, P.; Silbergeld, E.; Jaar, B.; Weaver, V. Blood cadmium and lead and chronic kidney disease in US adults: A joint analysis. Am. J. Epidemiol. 2009, 170, 1156-1164. [CrossRef] [PubMed]

198. Hellstrom, L.; Elinder, C.G.; Dahlberg, B.; Lundberg, M.; Jarup, L.; Persson, B.; Axelson, O. Cadmium exposure and end-stage renal disease. Am. J. Kidney Dis. 2001, 38, 1001-1008. [CrossRef] [PubMed]

199. Chen, B.; Lamberts, L.V.; Behets, G.J.; Zhao, T.; Zhou, M.; Liu, G.; Hou, X.; Guan, G.; D’Haese, P.C. Selenium, lead, and cadmium levels in renal failure patients in China. Biol. Trace Elem. Res. 2009, 131, 1-12. [CrossRef] [PubMed]

200. Gonick, H.C. Nephrotoxicity of cadmium \& lead. Ind. J. Med. Res. 2008, 128, 335-352.

201. Lauwerys, R.; Bernard, A.; Cardenas, A. Monitoring of early nephrotoxic effects of industrial chemicals. Toxicol. Lett. 1992, 64-65, 33-42. [CrossRef]

202. Ginsberg, G.L. Cadmium risk assessment in relation to background risk of chronic kidney disease. J. Toxicol. Environ. Health A 2012, 75, 374-390. [CrossRef] [PubMed]

203. Hwangbo, Y.; Weaver, V.M.; Tellez-Plaza, M.; Guallar, E.; Lee, B.K.; Navas-Acien, A. Blood cadmium and estimated glomerular filtration rate in Korean adults. Environ. Health Perspect. 2011, 119, 1800-1805. [CrossRef] [PubMed]

204. Porter, G.A. Risk factors for toxic nephropathies. Toxicol. Lett. 1989, 46, 269-279. [CrossRef]

205. Roels, H.A.; Hoet, P.; Lison, D. Usefulness of biomarkers of exposure to inorganic mercury, lead, or cadmium in controlling occupational and environmental risks of nephrotoxicity. Ren. Fail. 1999, 21, 251-262. [CrossRef] [PubMed]

206. Mueller, P.W.; Price, R.G.; Finn, W.F. New approaches for detecting thresholds of human nephrotoxicity using cadmium as an example. Environ. Health Perspect. 1998, 106, 227-230. [CrossRef] [PubMed]

207. Jayatilake, N.; Mendis, S.; Maheepala, P.; Mehta, F.R. Chronic kidney disease of uncertain aetiology: Prevalence and causative factors in a developing country. BMC Nephrol. 2013, 14, 180. [CrossRef] [PubMed]

208. Kim, N.H.; Hyun, Y.Y.; Lee, K.B.; Chang, Y.; Ryu, S.; Oh, K.H.; Ahn, C. Environmental heavy metal exposure and chronic kidney disease in the general population. J. Korean Med. Sci. 2015, 30, 272-277. [CrossRef] [PubMed]

209. Thomas, L.D.; Elinder, C.G.; Wolk, A.; Akesson, A. Dietary cadmium exposure and chronic kidney disease: A population-based prospective cohort study of men and women. Int. J. Hyg. Environ. Health 2014, 217, 720-725. [CrossRef] [PubMed]

210. Satarug, S.; Vesey, D.A.; Gobe, G.C. Kidney Cadmium Toxicity, Diabetes and High Blood Pressure: The Perfect Storm. Tohoku J. Exp. Med. 2017, 241, 65-87. [CrossRef] [PubMed]

211. Hayslett, J.P. Functional adaptation to reduction in renal mass. Physiol. Rev. 1979, 59, 137-164. [PubMed]

212. Zalups, R.K.; Fraser, J.; Koropatnick, J. Enhanced transcription of metallothionein genes in rat kidney: Effect of uninephrectomy and compensatory renal growth. Am. J. Physiol. 1995, 268, F643-F650. [PubMed]

213. Edwards, J.R.; Prozialeck, W.C. Cadmium, diabetes and chronic kidney disease. Toxicol. Appl. Pharmacol. 2009, 238, 289-293. [CrossRef] [PubMed]

214. Nordberg, G.F.; Jin, T.; Wu, X.; Lu, J.; Chen, L.; Lei, L.; Hong, F.; Nordberg, M. Prevalence of kidney dysfunction in humans-relationship to cadmium dose, metallothionein, immunological and metabolic factors. Biochimie 2009, 91, 1282-1285. [CrossRef] [PubMed]

215. Li, Y.; Zhang, Y.; Wang, W.; Wu, Y. Association of urinary cadmium with risk of diabetes: A meta-analysis. Environ. Sci. Pollut. Res. Int. 2017, 24, 10083-10090. [CrossRef] [PubMed]

216. Schrijvers, B.F.; De Vriese, A.S.; Flyvbjerg, A. From hyperglycemia to diabetic kidney disease: The role of metabolic, hemodynamic, intracellular factors and growth factors/cytokines. Endocr. Rev. 2004, 25, 971-1010. [CrossRef] [PubMed]

217. Bell, R.R.; Early, J.L.; Nonavinakere, V.K.; Mallory, Z. Effect of cadmium on blood glucose level in the rat. Toxicol. Lett. 1990, 54, 199-205. [CrossRef]

218. Chapatwala, K.D.; Boykin, M.; Butts, A.; Rajanna, B. Effect of intraperitoneally injected cadmium on renal and hepatic gluconeogenic enzymes in rats. Drug Chem. Toxicol. 1982, 5, 305-317. [CrossRef] [PubMed] 
219. Lei, L.J.; Jin, T.Y.; Zhou, Y.F. Insulin expression in rats exposed to cadmium. Biomed. Environ. Sci. 2007, 20, 295-301. [PubMed]

220. Merali, Z.; Singhal, R.L. Diabetogenic effects of chronic oral cadmium adminstration to neonatal rats. Br. J. Pharmacol. 1980, 69, 151-157. [CrossRef] [PubMed]

221. Lei, L.J.; Jin, T.Y.; Zhou, Y.F. Effects of cadmium on levels of insulin in rats. J. Hyg. Res. 2005, 34, 394-396.

222. Jin, T.; Nordberg, G.; Sehlin, J.; Wallin, H.; Sandberg, S. The susceptibility to nephrotoxicity of streptozotocin-induced diabetic rats subchronically exposed to cadmium chloride in drinking water. Toxicology 1999, 142, 69-75. [CrossRef]

223. Bernard, A.; Schadeck, C.; Cardenas, A.; Buchet, J.P.; Lauwerys, R. Potentiation of diabetic glomerulopathy in uninephrectomized rats subchronically exposed to cadmium. Toxicol. Lett. 1991, 58, 51-57. [CrossRef]

224. Jin, T.; Nordberg, G.F.; Sehlin, J.; Leffler, P.; Wu, J. The susceptibility of spontaneously diabetic mice to cadmium-metallothionein nephrotoxicity. Toxicology 1994, 89, 81-90. [CrossRef]

225. Haswell-Elkins, M.; Satarug, S.; O'Rourke, P.; Moore, M.; Ng, J.; McGrath, V.; Walmby, M. Striking association between urinary cadmium level and albuminuria among Torres Strait Islander people with diabetes. Environ. Res. 2008, 106, 379-383. [CrossRef] [PubMed]

226. Buchet, J.P.; Lauwerys, R.; Roels, H.; Bernard, A.; Bruaux, P.; Claeys, F.; Ducoffre, G.; de Plaen, P.; Staessen, J.; Amery, A.; et al. Renal effects of cadmium body burden of the general population. Lancet 1990, 336, 699-702. [CrossRef]

227. Satarug, S.; Ujjin, P.; Vanavanitkun, Y.; Baker, J.R.; Moore, M.R. Influence of body iron store status and cigarette smoking on cadmium body burden of healthy Thai women and men. Toxicol. Lett. 2004, 148, 177-185. [CrossRef] [PubMed]

228. Berglund, M.; Akesson, A.; Nermell, B.; Vahter, M. Intestinal absorption of dietary cadmium in women depends on body iron stores and fiber intake. Environ. Health Perspect. 1994, 102, 1058-1066. [CrossRef] [PubMed]

229. Akesson, A.; Berglund, M.; Schutz, A.; Bjellerup, P.; Bremme, K.; Vahter, M. Cadmium exposure in pregnancy and lactation in relation to iron status. Am. J. Public Health 2002, 92, 284-287. [CrossRef] [PubMed]

230. Kim, D.W.; Kim, K.Y.; Choi, B.S.; Youn, P.; Ryu, D.Y.; Klaassen, C.D.; Park, J.D. Regulation of metal transporters by dietary iron, and the relationship between body iron levels and cadmium uptake. Arch. Toxicol. 2007, 81, 327-334. [CrossRef] [PubMed]

231. Vesey, D.A. Transport pathways for cadmium in the intestine and kidney proximal tubule: Focus on the interaction with essential metals. Toxicol. Lett. 2010, 198, 13-19. [CrossRef] [PubMed]

232. DeWitt, R.D. Pediatric lead exposure and the water crisis in Flint, Michigan. J. Am. Acad. Phys. Assist. 2017, 30, 43-46. [CrossRef] [PubMed]

233. Kennedy, C.; Yard, E.; Dignam, T.; Buchanan, S.; Condon, S.; Brown, M.J.; Raymond, J.; Rogers, H.S.; Sarisky, J.; de Castro, R.; et al. Blood Lead Levels Among Children Aged . MMWR 2016, 65, 650-654. [PubMed]

234. Shah, K.K.; Oleske, J.M.; Gomez, H.F.; Davidow, A.L.; Bogden, J.D. Blood Lead Concentrations of Children in the United States: A Comparison of States Using Two Very Large Databases. J. Pediatr. 2017. [CrossRef] [PubMed]

235. Centers of Disease Control and Prevention (CDC). Very high blood lead levels among adults-United States, 2002-2011. MMWR 2013, 62, 967-971.

236. Raymond, J.; Brown, M.J. Childhood Blood Lead Levels in Children Aged . MMWR 2017, 66, 1-10. [PubMed]

237. Alarcon, W.A. Elevated Blood Lead Levels Among Employed Adults-United States, 1994-2013. MMWR 2016, 63, 59-65. [CrossRef] [PubMed]

238. Goyer, R.A. Lead toxicity: Current concerns. Environ. Health Perspect. 1993, 100, 177-187. [CrossRef] [PubMed]

239. Dapul, H.; Laraque, D. Lead poisoning in children. Adv. Pediatr. 2014, 61, 313-333. [CrossRef] [PubMed]

240. Fowler, B.A. Mechanisms of Kidney Cell Injury from Metals. Environ. Health Perspect. 1992, 100, 57-63. [CrossRef]

241. Smith, D.R.; Kahng, M.W.; Quintanilla-Vega, B.; Fowler, B.A. High-affinity renal lead-binding proteins in environmentally-exposed humans. Chem. Biol. Interact. 1998, 115, 39-52. [CrossRef] 
242. Oskarsson, A.; Squibb, K.S.; Fowler, B.A. Intracellular binding of lead in the kidney: The partial isolation and characterization of postmitochondrial lead binding components. Biochem. Biophys. Res. Commun. 1982, 104, 290-298. [CrossRef]

243. DuVal, G.; Fowler, B.A. Preliminary purification and characterization studies of a low molecular weight, high affinity cytosolic lead-binding protein in rat brain. Biochem. Biophys. Res. Commun. 1989, 159, 177-184. [CrossRef]

244. Fowler, B.A.; DuVal, G. Effects of lead on the kidney: Roles of high-affinity lead-binding proteins. Environ. Health Perspect. 1991, 91, 77-80. [CrossRef] [PubMed]

245. Swenberg, J.A.; Short, B.; Borghoff, S.; Strasser, J.; Charbonneau, M. The comparative pathobiology of alpha 2u-globulin nephropathy. Toxicol. Appl. Pharmacol. 1989, 97, 35-46. [CrossRef]

246. Goyer, R.A. Mechanisms of lead and cadmium nephrotoxicity. Toxicol. Lett. 1989, 46, 153-162. [CrossRef]

247. Marchetti, C. Role of calcium channels in heavy metal toxicity. ISRN Toxicol. 2013, 2013, 184360. [CrossRef] [PubMed]

248. Goyer, R.A. Toxic and essential metal interactions. Annu. Rev. Nutr. 1997, 17, 37-50. [CrossRef] [PubMed]

249. Ziegler, E.E.; Edwards, B.B.; Jensen, R.L.; Mahaffey, K.R.; Fomon, S.J. Absorption and retention of lead by infants. Pediatr. Res. 1978, 12, 29-34. [CrossRef] [PubMed]

250. Chen, J.; Li, M.; Lv, Q.; Chen, G.; Li, Y.; Li, S.; Mo, Y.; Ou, S.; Yuan, Z.; Huang, M.; et al. Blood lead level and its relationship to essential elements in preschool children from Nanning, China. J. Trace Elem. Med. Biol. 2015, 30, 137-141. [CrossRef] [PubMed]

251. Six, K.M.; Goyer, R.A. Experimental enhancement of lead toxicity by low dietary calcium. J. Lab. Clin. Med. 1970, 76, 933-942. [PubMed]

252. Bogden, J.D.; Gertner, S.B.; Christakos, S.; Kemp, F.W.; Yang, Z.; Katz, S.R.; Chu, C. Dietary calcium modifies concentrations of lead and other metals and renal calbindin in rats. J. Nutr. 1992, 122, 1351-1360. [PubMed]

253. Mahaffey, K.R.; Gartside, P.S.; Glueck, C.J. Blood lead levels and dietary calcium intake in 1- to 11-year-old children: The Second National Health and Nutrition Examination Survey, 1976 to 1980. Pediatrics 1986, 78, 257-262. [PubMed]

254. Blake, K.C.; Mann, M. Effect of calcium and phosphorus on the gastrointestinal absorption of $203 \mathrm{~Pb}$ in man. Environ. Res. 1983, 30, 188-194. [CrossRef]

255. Barton, J.C. Active transport of lead-210 by everted segments of rat duodenum. Am. J. Physiol. 1984, 247, G193-G198. [PubMed]

256. Giebisch, G.; Windhager, E. Transport of urea, glucose, phosphate, calcium, magnesium, and organic solutes. In Medical Physiology, 2nd ed.; Boron, W.F., Boulpaep, E.L., Eds.; Elsevier: Philadelphia, PA, USA, 2012; pp. 797-820.

257. Kerper, L.E.; Hinkle, P.M. Cellular uptake of lead is activated by depletion of intracellular calcium stores. J. Biol. Chem. 1997, 272, 8346-8352. [CrossRef] [PubMed]

258. Simons, T.J. Lead transport and binding by human erythrocytes in vitro. Pflugers Arch. 1993, 423, $307-313$. [CrossRef] [PubMed]

259. Simons, T.J. Lead-calcium interactions in cellular lead toxicity. Neurotoxicology 1993, 14, 77-85. [PubMed]

260. Simons, T.J.; Pocock, G. Lead enters bovine adrenal medullary cells through calcium channels. J. Neurochem. 1987, 48, 383-389. [CrossRef] [PubMed]

261. Peng, S.; Hajela, R.K.; Atchison, W.D. Characteristics of block by $\mathrm{Pb}^{2+}$ of function of human neuronal L-, N-, and R-type $\mathrm{Ca}^{2+}$ channels transiently expressed in human embryonic kidney 293 cells. Mol. Pharmacol. 2002, 62, 1418-1430. [CrossRef] [PubMed]

262. Chiu, T.Y.; Teng, H.C.; Huang, P.C.; Kao, F.J.; Yang, D.M. Dominant role of Orai1 with STIM1 on the cytosolic entry and cytotoxicity of lead ions. Toxicol. Sci. 2009, 110, 353-362. [CrossRef] [PubMed]

263. Pfleger, H.; Wolf, H.U. Activation of membrane-bound high-affinity calcium ion-sensitive adenosine triphosphatase of human erythrocytes by bivalent metal ions. Biochem. J. 1975, 147, 359-361. [CrossRef] [PubMed]

264. Alexander, J.; Aaseth, J.; Mikalsen, A. Excretion of lead in rat bile-The role of glutathione. Acta Pharmacol. Toxicol. 1986, 59 (Suppl. S7), 486-489. [CrossRef]

265. Patrick, L. Lead toxicity part II: The role of free radical damage and the use of antioxidants in the pathology and treatment of lead toxicity. Altern. Med. Rev. 2006, 11, 114-127. [PubMed] 
266. Basgen, J.M.; Sobin, C. Early chronic low-level lead exposure produces glomerular hypertrophy in young C57BL/6J mice. Toxicol. Lett. 2014, 225, 48-56. [CrossRef] [PubMed]

267. Ritz, E.; Mann, J.; Stoeppler, M. Lead and the kidney. Adv. Nephrol. Necker Hosp. 1988, 17, 241-274. [PubMed]

268. Navarro-Moreno, L.G.; Quintanar-Escorza, M.A.; Gonzalez, S.; Mondragon, R.; Cerbon-Solorzano, J.; Valdes, J.; Calderon-Salinas, J.V. Effects of lead intoxication on intercellular junctions and biochemical alterations of the renal proximal tubule cells. Toxicol. In Vitro 2009, 23, 1298-1304. [CrossRef] [PubMed]

269. Cardenas, A.; Roels, H.; Bernard, A.M.; Barbon, R.; Buchet, J.P.; Lauwerys, R.R.; Rosello, J.; Ramis, I.; Mutti, A.; Franchini, I.; et al. Markers of early renal changes induced by industrial pollutants. II. Application to workers exposed to lead. Br. J. Ind. Med. 1993, 50, 28-36. [CrossRef] [PubMed]

270. Soliman, M.M.; Baiomy, A.A.; Yassin, M.H. Molecular and Histopathological Study on the Ameliorative Effects of Curcumin Against Lead Acetate-Induced Hepatotoxicity and Nephrototoxicity in Wistar Rats. Biol. Trace Elem. Res. 2015, 167, 91-102. [CrossRef] [PubMed]

271. Zhou, R.; Xu, Y.; Shen, J.; Han, L.; Chen, X.; Feng, X.; Kuang, X. Urinary KIM-1: A novel biomarker for evaluation of occupational exposure to lead. Sci. Rep. 2016, 6, 38930. [CrossRef] [PubMed]

272. Garcon, G.; Leleu, B.; Marez, T.; Zerimech, F.; Haguenoer, J.M.; Furon, D.; Shirali, P. Biomonitoring of the adverse effects induced by the chronic exposure to lead and cadmium on kidney function: Usefulness of alpha-glutathione S-transferase. Sci. Total Environ. 2007, 377, 165-172. [CrossRef] [PubMed]

273. Zhang, Z.; Gao, X.; Guo, M.; Jiang, H.; Cao, Y.; Zhang, N. The Protective Effect of Baicalin Against Lead-Induced Renal Oxidative Damage in Mice. Biol. Trace Elem. Res. 2017, 175, 129-135. [CrossRef] [PubMed]

274. Wang, L.; Wang, H.; Hu, M.; Cao, J.; Chen, D.; Liu, Z. Oxidative stress and apoptotic changes in primary cultures of rat proximal tubular cells exposed to lead. Arch. Toxicol. 2009, 83, 417-427. [CrossRef] [PubMed]

275. Dewanjee, S.; Sahu, R.; Karmakar, S.; Gangopadhyay, M. Toxic effects of lead exposure in Wistar rats: Involvement of oxidative stress and the beneficial role of edible jute (Corchorus olitorius) leaves. Food Chem. Toxicol. 2013, 55, 78-91. [CrossRef] [PubMed]

276. Liu, G.; Wang, Z.K.; Wang, Z.Y.; Yang, D.B.; Liu, Z.P.; Wang, L. Mitochondrial permeability transition and its regulatory components are implicated in apoptosis of primary cultures of rat proximal tubular cells exposed to lead. Arch. Toxicol. 2016, 90, 1193-1209. [CrossRef] [PubMed]

277. Bonora, M.; Morganti, C.; Morciano, G.; Giorgi, C.; Wieckowski, M.R.; Pinton, P. Comprehensive analysis of mitochondrial permeability transition pore activity in living cells using fluorescence-imaging-based techniques. Nat. Protoc. 2016, 11, 1067-1080. [CrossRef] [PubMed]

278. Wang, L.; Cao, J.; Chen, D.; Liu, X.; Lu, H.; Liu, Z. Role of oxidative stress, apoptosis, and intracellular homeostasis in primary cultures of rat proximal tubular cells exposed to cadmium. Biol. Trace Elem. Res. 2009, 127, 53-68. [CrossRef] [PubMed]

279. Jacotot, E.; Deniaud, A.; Borgne-Sanchez, A.; Touat, Z.; Briand, J.P.; Le Bras, M.; Brenner, C. Therapeutic peptides: Targeting the mitochondrion to modulate apoptosis. Biochim. Biophys. Acta 2006, 1757, 1312-1323. [CrossRef] [PubMed]

280. Goldstein, G.W.; Ar, D. Lead activates calmodulin sensitive processes. Life Sci. 1983, 33, 1001-1006. [CrossRef]

281. Habermann, E.; Crowell, K.; Janicki, P. Lead and other metals can substitute for $\mathrm{Ca}^{2+}$ in calmodulin. Arch. Toxicol. 1983, 54, 61-70. [CrossRef] [PubMed]

282. Stoclet, J.C.; Gerard, D.; Kilhoffer, M.C.; Lugnier, C.; Miller, R.; Schaeffer, P. Calmodulin and its role in intracellular calcium regulation. Prog. Neurobiol. 1987, 29, 321-364. [CrossRef]

283. Wang, H.; Wang, Z.K.; Jiao, P.; Zhou, X.P.; Yang, D.B.; Wang, Z.Y.; Wang, L. Redistribution of subcellular calcium and its effect on apoptosis in primary cultures of rat proximal tubular cells exposed to lead. Toxicology 2015, 333, 137-146. [CrossRef] [PubMed]

284. Zhang, J.; Cao, H.; Zhang, Y.; Ma, J.; Wang, J.; Gao, Y.; Zhang, X.; Zhang, F.; Chu, L. Nephroprotective effect of calcium channel blockers against toxicity of lead exposure in mice. Toxicol. Lett. 2013, 218, 273-280. [CrossRef] [PubMed]

285. Staessen, J.; Yeoman, W.B.; Fletcher, A.E.; Markowe, H.L.; Marmot, M.G.; Rose, G.; Semmence, A.; Shipley, M.J.; Bulpitt, C.J. Blood lead concentration, renal function, and blood pressure in London civil servants. Br. J. Ind. Med. 1990, 47, 442-447. [CrossRef] [PubMed]

286. Ekong, E.B.; Jaar, B.G.; Weaver, V.M. Lead-related nephrotoxicity: A review of the epidemiologic evidence. Kidney Int. 2006, 70, 2074-2084. [CrossRef] [PubMed] 
287. Fadrowski, J.J.; Navas-Acien, A.; Tellez-Plaza, M.; Guallar, E.; Weaver, V.M.; Furth, S.L. Blood lead level and kidney function in US adolescents: The Third National Health and Nutrition Examination Survey. Arch. Int. Med. 2010, 170, 75-82. [CrossRef] [PubMed]

288. Spector, J.T.; Navas-Acien, A.; Fadrowski, J.; Guallar, E.; Jaar, B.; Weaver, V.M. Associations of blood lead with estimated glomerular filtration rate using MDRD, CKD-EPI and serum cystatin C-based equations. Nephrol. Dial. Transplant. 2011, 26, 2786-2792. [CrossRef] [PubMed]

289. Landrigan, P.J. Current issues in the epidemiology and toxicology of occupational exposure to lead. Environ. Health Perspect. 1990, 89, 61-66. [CrossRef] [PubMed]

290. Hernandez-Serrato, M.I.; Fortoul, T.I.; Rojas-Martinez, R.; Mendoza-Alvarado, L.R.; Canales-Trevino, L.; Bochichio-Riccardelli, T.; Avila-Costa, M.R.; Olaiz-Fernandez, G. Lead blood concentrations and renal function evaluation: Study in an exposed Mexican population. Environ. Res. 2006, 100, 227-231. [CrossRef] [PubMed]

291. Chung, S.; Chung, J.H.; Kim, S.J.; Koh, E.S.; Yoon, H.E.; Park, C.W.; Chang, Y.S.; Shin, S.J. Blood lead and cadmium levels and renal function in Korean adults. Clin. Exp. Nephrol. 2014, 18, 726-734. [CrossRef] [PubMed]

292. Sommar, J.N.; Svensson, M.K.; Bjor, B.M.; Elmstahl, S.I.; Hallmans, G.; Lundh, T.; Schon, S.M.; Skerfving, S.; Bergdahl, I.A. End-stage renal disease and low level exposure to lead, cadmium and mercury; a population-based, prospective nested case-referent study in Sweden. Environ. Health 2013, 12, 9. [CrossRef] [PubMed]

293. Agency for Toxic Substances and Disease Registry (ATSDR). Toxicological Profile for Mercury. In ATSDR's Toxicological Profiles; U.S. Department of Health and Human Services, Public Health Service (PHS); Centers for Disease Control and Prevention: Atlanta, GA, USA, 2008.

294. Clarkson, T.W.; Magos, L. The toxicology of mercury and its chemical compounds. Crit. Rev. Toxicol. 2006, 36, 609-662. [CrossRef] [PubMed]

295. Rooney, J.P. The role of thiols, dithiols, nutritional factors and interacting ligands in the toxicology of mercury. Toxicology 2007, 234, 145-156. [CrossRef] [PubMed]

296. Zalups, R.K. Molecular interactions with mercury in the kidney. Pharmacol. Rev. 2000, 52, 113-143. [PubMed]

297. Risher, J.F.; De Rosa, C.T. Inorganic: The other mercury. J. Environ. Health 2007, 70, 9-16. [PubMed]

298. Gage, J.C. Distribution and Excretion of Methyl and Phenyl Mercury Salts. Br. J. Ind. Med. 1964, $21,197-202$. [CrossRef] [PubMed]

299. Norseth, T.; Clarkson, T.W. Studies on the biotransformation of $203 \mathrm{Hg}$-labeled methyl mercury chloride in rats. Arch. Environ. Health 1970, 21, 717-727. [CrossRef] [PubMed]

300. Norseth, T.; Clarkson, T.W. Biotransformation of methylmercury salts in the rat studied by specific determination of inorganic mercury. Biochem. Pharmacol. 1970, 19, 2775-2783. [CrossRef]

301. Omata, S.; Sato, M.; Sakimura, K.; Sugano, H. Time-dependent accumulation of inorganic mercury in subcellular fractions of kidney, liver, and brain of rats exposed to methylmercury. Arch. Toxicol. 1980, 44, 231-241. [CrossRef] [PubMed]

302. Nielsen, J.B. Toxicokinetics of mercuric chloride and methylmercuric chloride in mice. J. Toxicol. Environ. Health 1992, 37, 85-122. [CrossRef] [PubMed]

303. Zalups, R.K. Early aspects of the intrarenal distribution of mercury after the intravenous administration of mercuric chloride. Toxicology 1993, 79, 215-228. [CrossRef]

304. Murphy, M.J.; Culliford, E.J.; Parsons, V. A case of poisoning with mercuric chloride. Resuscitation 1979, 7, 35-44. [CrossRef]

305. Rowens, B.; Guerrero-Betancourt, D.; Gottlieb, C.A.; Boyes, R.J.; Eichenhorn, M.S. Respiratory failure and death following acute inhalation of mercury vapor. A clinical and histologic perspective. Chest 1991, 99, 185-190. [CrossRef] [PubMed]

306. Samuels, E.R.; Heick, H.M.; McLaine, P.N.; Farant, J.P. A case of accidental inorganic mercury poisoning. J. Anal. Toxicol. 1982, 6, 120-122. [CrossRef] [PubMed]

307. Yasutake, A.; Hirayama, K.; Inoue, M. Mechanism of urinary excretion of methylmercury in mice. Arch. Toxicol. 1989, 63, 479-483. [CrossRef] [PubMed]

308. Hughes, W.L. A physicochemical rationale for the biological activity of mercury and its compounds. Ann. N. Y. Acad. Sci. 1957, 65, 454-460. [CrossRef] [PubMed] 
309. Fuhr, B.J.; Rabenstein, D.L. Nuclear magnetic resonance studies of the solution chemistry of metal complexes. IX. The binding of cadmium, zinc, lead, and mercury by glutathione. J. Am. Chem. Soc. 1973, 95, 6944-6950. [CrossRef] [PubMed]

310. Rubino, F.M.; Verduci, C.; Giampiccolo, R.; Pulvirenti, S.; Brambilla, G.; Colombi, A. Molecular characterization of homo- and heterodimeric mercury(II)-bis-thiolates of some biologically relevant thiols by electrospray ionization and triple quadrupole tandem mass spectrometry. J. Am. Soc. Mass Spectrom. 2004, 15, 288-300. [CrossRef] [PubMed]

311. Cannon, V.T.; Barfuss, D.W.; Zalups, R.K. Molecular homology and the luminal transport of $\mathrm{Hg}^{2+}$ in the renal proximal tubule. J. Am. Soc. Nephrol. 2000, 11, 394-402. [PubMed]

312. Cannon, V.T.; Zalups, R.K.; Barfuss, D.W. Amino acid transporters involved in luminal transport of mercuric conjugates of cysteine in rabbit proximal tubule. J. Pharmacol. Exp. Ther. 2001, 298, 780-789. [PubMed]

313. Zalups, R.K. Basolateral uptake of inorganic mercury in the kidney. Toxicol. Appl. Pharmacol. 1998, 151, 192-199. [CrossRef] [PubMed]

314. Zalups, R.K.; Lash, L.H. Binding of mercury in renal brush-border and basolateral membrane-vesicles. Biochem. Pharmacol. 1997, 53, 1889-1900. [CrossRef]

315. Zalups, R.K.; Minor, K.H. Luminal and basolateral mechanisms involved in the renal tubular uptake of inorganic mercury. J. Toxicol. Environ. Health 1995, 46, 73-100. [CrossRef] [PubMed]

316. Zalups, R.K.; Barfuss, D.W. Accumulation and handling of inorganic mercury in the kidney after coadministration with glutathione. J. Toxicol. Environ. Health 1995, 44, 385-399. [CrossRef] [PubMed]

317. Zalups, R.K.; Barfuss, D.W. Nephrotoxicity of inorganic mercury co-administrated with L-cysteine. Toxicology 1996, 109, 15-29. [CrossRef]

318. Zalups, R.K.; Barfuss, D.W. Participation of mercuric conjugates of cysteine, homocysteine, and $\mathrm{N}$-acetylcysteine in mechanisms involved in the renal tubular uptake of inorganic mercury. J. Am. Soc. Nephrol. 1998, 9, 551-561. [PubMed]

319. Bridges, C.C.; Bauch, C.; Verrey, F.; Zalups, R.K. Mercuric conjugates of cysteine are transported by the amino acid transporter system $\mathrm{b}(0,+)$ : Implications of molecular mimicry. J. Am. Soc. Nephrol. 2004, 15, 663-673. [CrossRef] [PubMed]

320. Bridges, C.C.; Zalups, R.K. Homocysteine, system $b^{0,+}$ and the renal epithelial transport and toxicity of inorganic mercury. Am. J. Pathol. 2004, 165, 1385-1394. [CrossRef]

321. Bridges, C.C.; Zalups, R.K. System $\mathrm{B}^{0,+}$ and the transport of thiol-S-conjugates of methylmercury. J. Pharmacol. Exp. Ther. 2006, 319, 948-956. [CrossRef] [PubMed]

322. Zalups, R.K.; Barfuss, D.W. Pretreatment with p-aminohippurate inhibits the renal uptake and accumulation of injected inorganic mercury in the rat. Toxicology 1995, 103, 23-35. [CrossRef]

323. Zalups, R.K.; Barfuss, D.W. Small aliphatic dicarboxylic acids inhibit renal uptake of administered mercury. Toxicol. Appl. Pharmacol. 1998, 148, 183-193. [CrossRef] [PubMed]

324. Zalups, R.K. Organic anion transport and action of gamma-glutamyl transpeptidase in kidney linked mechanistically to renal tubular uptake of inorganic mercury. Toxicol. Appl. Pharmacol. 1995, 132, 289-298. [CrossRef] [PubMed]

325. Zalups, R.K. Basolateral uptake of mercuric conjugates of $N$-acetylcysteine and cysteine in the kidney involves the organic anion transport system. J. Toxicol. Environ. Health A 1998, 55, 13-29. [CrossRef] [PubMed]

326. Ferrier, B.; Martin, M.; Roch-Ramel, F. Effects of p-aminohippurate and pyrazinoate on the renal excretion of salicylate in the rat: A micropuncture study. J. Pharmacol. Exp. Ther. 1983, 224, 451-458. [PubMed]

327. Koh, A.S.; Simmons-Willis, T.A.; Pritchard, J.B.; Grassl, S.M.; Ballatori, N. Identification of a mechanism by which the methylmercury antidotes $N$-acetylcysteine and dimercaptopropanesulfonate enhance urinary metal excretion: Transport by the renal organic anion transporter-1. Mol. Pharmacol. 2002, 62, 921-926. [CrossRef] [PubMed]

328. Kojima, R.; Sekine, T.; Kawachi, M.; Cha, S.H.; Suzuki, Y.; Endou, H. Immunolocalization of multispecific organic anion transporters, OAT1, OAT2, and OAT3, in rat kidney. J. Am. Soc. Nephrol. 2002, 13, 848-857. [PubMed]

329. Motohashi, H.; Sakurai, Y.; Saito, H.; Masuda, S.; Urakami, Y.; Goto, M.; Fukatsu, A.; Ogawa, O.; Inui, K. Gene expression levels and immunolocalization of organic ion transporters in the human kidney. J. Am. Soc. Nephrol. 2002, 13, 866-874. [PubMed] 
330. Pritchard, J.B. Coupled transport of p-aminohippurate by rat kidney basolateral membrane vesicles. Am. J. Physiol. 1988, 255, F597-F604. [PubMed]

331. Shimomura, A.; Chonko, A.M.; Grantham, J.J. Basis for heterogeneity of para-aminohippurate secretion in rabbit proximal tubules. Am. J. Physiol. 1981, 240, F430-F436. [PubMed]

332. Tanaka, T.; Naganuma, A.; Miura, N.; Imura, N. Role of testosterone in gamma-glutamyltranspeptidasedependent renal methylmercury uptake in mice. Toxicol. Appl. Pharmacol. 1992, 112, 58-63. [CrossRef]

333. Ullrich, K.J.; Rumrich, G.; Fritzsch, G.; Kloss, S. Contraluminal para-aminohippurate (PAH) transport in the proximal tubule of the rat kidney. II. Specificity: Aliphatic dicarboxylic acids. Pflugers Arch. 1987, 408, 38-45. [CrossRef] [PubMed]

334. Zalups, R.K.; Ahmad, S. Handling of cysteine S-conjugates of methylmercury in MDCK cells expressing human OAT1. Kidney Int. 2005, 68, 1684-1699. [CrossRef] [PubMed]

335. Zalups, R.K.; Ahmad, S. Handling of the homocysteine $S$-conjugate of methylmercury by renal epithelial cells: Role of organic anion transporter 1 and amino acid transporters. J. Pharmacol. Exp. Ther. 2005, 315, 896-904. [CrossRef] [PubMed]

336. Zalups, R.K.; Ahmad, S. Transport of N-acetylcysteine S-conjugates of methylmercury in Madin-Darby canine kidney cells stably transfected with human isoform of organic anion transporter 1. J. Pharmacol. Exp. Ther. 2005, 314, 1158-1168. [CrossRef] [PubMed]

337. Aslamkhan, A.G.; Han, Y.H.; Yang, X.P.; Zalups, R.K.; Pritchard, J.B. Human renal organic anion transporter 1-dependent uptake and toxicity of mercuric-thiol conjugates in Madin-Darby canine kidney cells. Mol. Pharmacol. 2003, 63, 590-596. [CrossRef] [PubMed]

338. Zalups, R.K.; Ahmad, S. Homocysteine and the renal epithelial transport and toxicity of inorganic mercury: Role of basolateral transporter organic anion transporter 1. J. Am. Soc. Nephrol. 2004, 15, 2023-2031. [CrossRef] [PubMed]

339. Zalups, R.K.; Aslamkhan, A.G.; Ahmad, S. Human organic anion transporter 1 mediates cellular uptake of cysteine-S conjugates of inorganic mercury. Kidney Int. 2004, 66, 251-261. [CrossRef] [PubMed]

340. Cherian, M.G.; Clarkson, T.W. Biochemical changes in rat kidney on exposure to elemental mercury vapor: Effect on biosynthesis of metallothionein. Chem. Biol. Interact. 1976, 12, 109-120. [CrossRef]

341. Zalups, R.K.; Koropatnick, J. Temporal changes in metallothionein gene transcription in rat kidney and liver: Relationship to content of mercury and metallothionein protein. J. Pharmacol. Exp. Ther. 2000, 295, 74-82. [PubMed]

342. Ruprecht, J. Scientific Monograph for Dimaval; Heyltex Corporation: Houston, TX, USA, 2008.

343. Aposhian, H.V. DMSA and DMPS-Water soluble antidotes for heavy metal poisoning. Annu. Rev. Pharmacol. Toxicol. 1983, 23, 193-215. [CrossRef] [PubMed]

344. Aposhian, H.V.; Maiorino, R.M.; Gonzalez-Ramirez, D.; Zuniga-Charles, M.; Xu, Z.; Hurlbut, K.M.; Junco-Munoz, P.; Dart, R.C.; Aposhian, M.M. Mobilization of heavy metals by newer, therapeutically useful chelating agents. Toxicology 1995, 97, 23-38. [CrossRef]

345. Aposhian, H.V.; Maiorino, R.M.; Rivera, M.; Bruce, D.C.; Dart, R.C.; Hurlbut, K.M.; Levine, D.J.; Zheng, W.; Fernando, Q.; Carter, D.; et al. Human studies with the chelating agents, DMPS and DMSA. J. Toxicol. Clin. Toxicol. 1992, 30, 505-528. [CrossRef] [PubMed]

346. Planas-Bohne, F. The effect of 2,3-dimercaptorpropane-1-sulfonate and dimercaptosuccinic acid on the distribution and excretion of mercuric chloride in rats. Toxicology 1981, 19, 275-278. [CrossRef]

347. Zalups, R.K. Influence of 2,3-dimercaptopropane-1-sulfonate (DMPS) and meso-2,3-dimercaptosuccinic acid (DMSA) on the renal disposition of mercury in normal and uninephrectomized rats exposed to inorganic mercury. J. Pharmacol. Exp. Ther. 1993, 267, 791-800. [PubMed]

348. Zalups, R.K.; Bridges, C.C. Relationships between the renal handling of DMPS and DMSA and the renal handling of mercury. Chem. Res. Toxicol. 2012, 25, 1825-1838. [CrossRef] [PubMed]

349. Rodiger, M.; Zhang, X.; Ugele, B.; Gersdorff, N.; Wright, S.H.; Burckhardt, G.; Bahn, A. Organic anion transporter 3 (OAT3) and renal transport of the metal chelator 2,3-dimercapto-1-propanesulfonic acid (DMPS). Can. J. Physiol. Pharmacol. 2010, 88, 141-146. [CrossRef] [PubMed]

350. Bahn, A.; Knabe, M.; Hagos, Y.; Rodiger, M.; Godehardt, S.; Graber-Neufeld, D.S.; Evans, K.K.; Burckhardt, G.; Wright, S.H. Interaction of the metal chelator 2,3-dimercapto-1-propanesulfonate with the rabbit multispecific organic anion transporter 1 (rbOAT1). Mol. Pharmacol. 2002, 62, 1128-1136. [CrossRef] [PubMed] 
351. Burckhardt, B.C.; Drinkuth, B.; Menzel, C.; Konig, A.; Steffgen, J.; Wright, S.H.; Burckhardt, G. The renal $\mathrm{Na}(+)$-dependent dicarboxylate transporter, $\mathrm{NaDC}-3$, translocates dimethyl- and disulfhydryl-compounds and contributes to renal heavy metal detoxification. J. Am. Soc. Nephrol. 2002, 13, 2628-2638. [CrossRef] [PubMed]

352. Islinger, F.; Gekle, M.; Wright, S.H. Interaction of 2,3-dimercapto-1-propane sulfonate with the human organic anion transporter hOAT1. J. Pharmacol. Exp. Ther. 2001, 299, 741-747. [PubMed]

353. Bridges, C.C.; Joshee, L.; Zalups, R.K. MRP2 and the DMPS- and DMSA-mediated elimination of mercury in TR(-) and control rats exposed to thiol S-conjugates of inorganic mercury. Toxicol. Sci. 2008, 105, 211-220. [CrossRef] [PubMed]

354. Bridges, C.C.; Joshee, L.; Zalups, R.K. Multidrug resistance proteins and the renal elimination of inorganic mercury mediated by 2,3-dimercaptopropane-1-sulfonic acid and meso-2,3-dimercaptosuccinic acid. J. Pharmacol. Exp. Ther. 2008, 324, 383-390. [CrossRef] [PubMed]

355. Bridges, C.C.; Joshee, L.; Zalups, R.K. Effect of DMPS and DMSA on the Placental and Fetal Disposition of Methylmercury. Placenta 2009, 30, 800-805. [CrossRef] [PubMed]

356. Bridges, C.C.; Zalups, R.K.; Joshee, L. Toxicological significance of renal Bcrp: Another potential transporter in the elimination of mercuric ions from proximal tubular cells. Toxicol. Appl. Pharmacol. 2015, 285, 110-117. [CrossRef] [PubMed]

357. Aremu, D.A.; Madejczyk, M.S.; Ballatori, N. N-acetylcysteine as a potential antidote and biomonitoring agent of methylmercury exposure. Environ. Health Perspect. 2008, 116, 26-31. [CrossRef] [PubMed]

358. Madejczyk, M.S.; Aremu, D.A.; Simmons-Willis, T.A.; Clarkson, T.W.; Ballatori, N. Accelerated urinary excretion of methylmercury following administration of its antidote $N$-acetylcysteine requires Mrp2/Abcc2, the apical multidrug resistance-associated protein. J. Pharmacol. Exp. Ther. 2007, 322, 378-384. [CrossRef] [PubMed]

359. McDowell, E.M.; Nagle, R.B.; Zalme, R.C.; McNeil, J.S.; Flamenbaum, W.; Trump, B.F. Studies on the pathophysiology of acute renal failure. I. Correlation of ultrastructure and function in the proximal tubule of the rat following administration of mercuric chloride. Virchows Arch. B Cell Pathol. 1976, 22, 173-196. [PubMed]

360. Zalme, R.C.; McDowell, E.M.; Nagle, R.B.; McNeil, J.S.; Flamenbaum, W.; Trump, B.F. Studies on the pathophysiology of acute renal failure. II. A histochemical study of the proximal tubule of the rat following administration of mercuric chloride. Virchows Arch. B Cell Pathol. 1976, 22, 197-216. [PubMed]

361. Rodin, A.E.; Crowson, C.N. Mercury nephrotoxicity in the rat. 2. Investigation of the intracellular site of mercury nephrotoxicity by correlated serial time histologic and histoenzymatic studies. Am. J. Pathol. 1962, 41, 485-499. [PubMed]

362. Gritzka, T.L.; Trump, B.F. Renal tubular lesions caused by mercuric chloride. Electron microscopic observations: Degeneration of the pars recta. Am. J. Pathol. 1968, 52, 1225-1277. [PubMed]

363. Zalups, R.K. Evidence for basolateral uptake of cadmium in the kidneys of rats. Toxicol. Appl. Pharmacol. 2000, 164, 15-23. [CrossRef] [PubMed]

364. Gotelli, C.A.; Astolfi, E.; Cox, C.; Cernichiari, E.; Clarkson, T.W. Early biochemical effects of an organic mercury fungicide on infants: “dose makes the poison". Science 1985, 227, 638-640. [CrossRef] [PubMed]

(C) 2017 by the authors. Licensee MDPI, Basel, Switzerland. This article is an open access article distributed under the terms and conditions of the Creative Commons Attribution (CC BY) license (http://creativecommons.org/licenses/by/4.0/). 